\title{
Article \\ Thermal, Mechanical, Morphological and Aesthetical Properties of Rotational Molding PE/Pine Wood Sawdust Composites
}

\author{
Carla I. Martins *(D), Vitória Gil and Sara Rocha
}

check for updates

Citation: Martins, C.I.; Gil, V.; Rocha, S. Thermal, Mechanical, Morphological and Aesthetical Properties of Rotational Molding PE/Pine Wood Sawdust Composites. Polymers 2022, 14, 193. https:// doi.org/10.3390/polym14010193

Academic Editor: Shazed Aziz

Received: 18 November 2021

Accepted: 25 December 2021

Published: 4 January 2022

Publisher's Note: MDPI stays neutral with regard to jurisdictional claims in published maps and institutional affiliations.

Copyright: (C) 2022 by the authors. Licensee MDPI, Basel, Switzerland. This article is an open access article distributed under the terms and conditions of the Creative Commons Attribution (CC BY) license (https:// creativecommons.org/licenses/by/ $4.0 /)$.
Institute for Polymers and Composites, University of Minho, Campus de Azurém, 4800-058 Guimaraes, Portugal; vitoriagilpc@gmail.com (V.G.); sararocha0@gmail.com (S.R.)

* Correspondence: cmartins@dep.uminho.pt

\begin{abstract}
This research addresses the importance of pine wood sawdust granulometry on the processing of medium-density polyethylene (MDPE)/wood composites by rotational molding and its effects on the morphological, mechanical and aesthetical properties of parts, aiming to contribute for the development of sustainable wood polymer composites (WPC) for rotational molding applications. Pine wood sawdust was sieved $(<150,150,300,500,710,>1000 \mu \mathrm{m})$ and analyzed for its physical, morphological and thermal characteristics. Rotational molded parts were produced with matrix/wood ratios from $90 / 10$ to $70 / 30 \mathrm{wt} \%$ considering different wood granulometries. As a natural material, wood changed its color during processing. Granulometries below $500 \mu \mathrm{m}$ presented better sintering, homogeneity and less part defects. Furthermore, 300-500 $\mu \mathrm{m}$ favored the impact resistance (1316 N), as irregular brick-shaped wood was able to anchor to PE despite the weak interfacial adhesion observed. The increase of wood content from 10 to $30 \%$ reduced the impact properties by $40 \%$, as a result of a highly porous structure formed, revealing sintering difficulties during processing. WPC parts of differentiated aesthetics and functionalities were achieved by rotational molding. A clear relationship between wood granulometry and WPC processing, structure and properties was identified.
\end{abstract}

Keywords: rotational molding; wood-polymer-composites; wood sawdust; polyethylene; thermal properties; morphology; mechanical properties

\section{Introduction}

The human awareness to reduce environmental impact and to reach sustainability, is leading to the effort of industrial waste reuse and the development of ecologically viable materials, from renewable resources. This demand has been growing over the last decades proving that bio economy and circular economy strategies are the solution that can match the scale of an emerging area of polymer composites and the production of high value biobased products [1-4]. However, products structural design may be necessary to preserve product functionality, material properties and economic value for longer time [5].

Natural fibers are an example of renewable material that have exceptional attributes such as low density, low cost, abundance in nature, renewability and marketing appeal [6]. They prove to be good alternatives to inorganic materials and a successful solution for wood polymer composites (WPC) that makes use of organic materials with virgin, recycled or green plastics, reducing dependency on petroleum-based raw materials [3,7-9]. Moreover, they offer the advantages of enhancing acoustic performance, reduced weight, lower production costs and biodegradability [10]. WPC can be easily processed through typical processing techniques, such as extrusion, injection molding, compression molding or thermoforming and they can also be manufactured like common plastics [11]. More recently, there have been several studies on new production technologies like additive manufacturing based on extrusion processes and laser sintering [12]. WPC can be applied in a wide range of applications but mostly they are found in the construction sectors [13-16] as lumbers, automotive and electrical sectors, offering cost-competitive products of lighter environmental footprint and unique aesthetic appeal. 
The wood components in WPC are generally used in sawdust form or small fibers (sawdust, off-cuts and shavings) as they are a by-product of the wood/timber industry produced by the cutting, sawing or grinding of timber. For that reason, they are irregular in shape and their size distribution can range from Over Size (OS > $710 \mu \mathrm{m})$, Coarse Particle Size (CPS $=350 \sim 710 \mu \mathrm{m})$ and Fine Particle Size (FPS $=177 \sim 250 \mu \mathrm{m})$, which affects the particles density, porosity and water retention. These physical properties of sawdust are dependent of the wood species [17].

The market of WPC is promising for obtaining rotomolded parts with less polymeric material and aesthetic appearance of natural wood, which can be used in furniture, playgrounds and automotive parts, among others [18-20]. Rotational molding is a technique used to produce hollow seamless parts, in which the processing cycle consists in four stages: charging the powder material, heating the material so that polymer can adhere to the mold surfaces and, cooling the part for solidification and demolding. During these stages the mold rotates bi-axially so that material can reach all the surfaces of the mold [21-23]. This technique poses a challenge for several materials, including natural ones, due to the possibility of thermooxidative degradation during processing, as a result of high temperature and long cycle time applied with impact on aesthetics, morphological and mechanical properties [24-28]. In case of natural lignocellulosic materials, they are formed by a chemical complex of cellulose, hemicellulose, lignin and extractives and inorganics [29,30], which are known to present different degradation profiles depending on its composition and temperature applied. Therefore, molding parameters must be carefully selected to avoid wood thermal degradation. Furthermore, the poor adhesion between polymers and natural fibers and the reduction of the sintering capability of the composite materials, that increases part porosity, are responsible for low mechanical properties [31,32]. Some strategies such as chemical treatment of the fibers and the use of a coupling agent were often used to improve the adhesion of the interface between the polymer matrix and the lignocellulosic filler [9,33-36].

In case of no treatment for natural and ecological featuring, very recent study from Arribasplata-Seguin et al. [32] shows the need for careful selection of processing parameters. Only with that the sintering process of wood plastic composites is improved with determinant effects on the mechanical properties. There is also an understanding that acceptable mechanical properties can be obtained when low contents of natural materials are incorporated $(10-15 \%)[37,38]$. For high fiber contents, fiber wettability by the polymer is difficult and fiber agglomeration may occur. The wood granulometry is also discussed by few authors, indicating better composite performance for small particle sizes, namely maple wood fiber size of 125-250 $\mu \mathrm{m}$ [39] and pine particles between 297-500 $\mu \mathrm{m}$ [32].

Several studies are found in literature dedicated to rotational molding using lignocellulosic materials [19]. Some of these used the following organic materials: jute, sisal and cabuya [31,40,41], wood fiber [32,40], flax [18,41], banana and abaca [42], agave [25,33,35,43], pine wood [32,33], coir [33], maple wood [18,37-39,44], hemp [18,34], cork [45] and bamboo [46]. Despite the variety of studies on WPC for rotational molding, there are still few real successful applications using these materials. The lack of studies using pine wood for rotational molding applications and that being a major resource in Portugal motivated the work carried in this study.

Polymer wood composites are a trend and a society demand nowadays. To create differentiated products with high value, ecological, sustainable, aesthetic and functional characteristics there is the need for a complete understanding of the materials used, its processability and the final characteristics of the products obtained. Materials performance depends on wood type, granulometry and content, sintering process and interaction with polymer matrix. This study addresses those subjects focusing on the granulometry and content of pine wood sawdust/MDPE composites produced by rotational molding. The work initiates with the characterization of pine wood sawdust, the production of polymer/wood composites and finally a full characterization of products, from its morphological and mechanical performance to aesthetics, namely, color, visual appearance and defects. This 
study is in line with other recently published articles in the finding of new materials for rotational molding $[9,25,32,45,46]$.

\section{Materials and Methods}

\subsection{Pine Wood Sawdust and Polymer Materials}

Sawdust obtained from wood processing stages of Portuguese pine (Pinus Pinaster) was kindly supplied by A. F. Fábrica de Madeiras, Lda (Braga, Portugal). As received material (Figure 1A) was sieved using a Fritsch Analysette 3 Spartan (Fritsch GmbH, IdarOberstein, Germany) sieve to be separated into different granulometries, namely $>1000 \mu \mathrm{m}$, $710 \mu \mathrm{m}, 500 \mu \mathrm{m}, 300 \mu \mathrm{m}$ and $<150 \mu \mathrm{m}$. Prior to the procedure the wood sawdust was dried in a Binder oven (BINDER GmbH, Tuttlingen, Germany) at $50{ }^{\circ} \mathrm{C}$ during $6 \mathrm{~h}$. The polymer used in the preparation of the wood-based composites was medium-density polyethylene (MDPE), Advancene EM-3405-UVH, from ETHYDCO (Alexandria, Egypt) with MFI of $5 \mathrm{~g} / 10 \mathrm{~min}\left(190^{\circ} \mathrm{C} / 2.16 \mathrm{~kg}\right)$, bulk density of $330-390 \mathrm{~kg} / \mathrm{m}^{3}$ and maximum particle size of $500 \mu \mathrm{m}$ (Figure 1B).
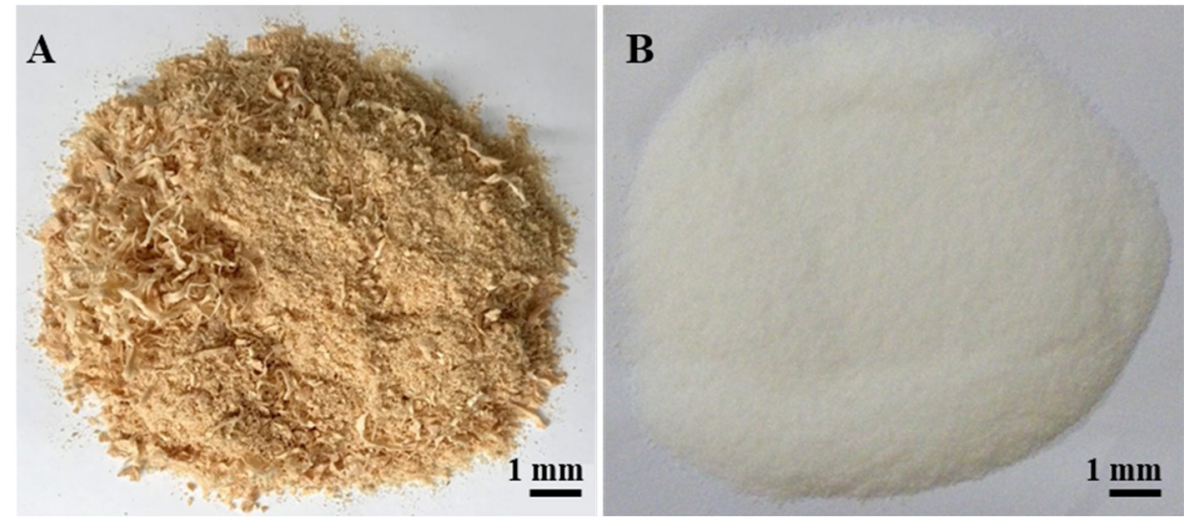

Figure 1. Raw materials: (A) Pine wood sawdust and (B) MDPE.

\subsection{Apparent Density}

The apparent density of wood sawdust with different granulometries were determined considering the following procedure, following an adaptation of ASTM D1895-96 (2010), method C: $10 \mathrm{~g}$ of wood particles were loosely dropped to a $250 \mathrm{~mL}$ dry graduated cylindrical cup. The wood sawdust was leveled without compressing and the apparent volume was read. Equation (1) was used to calculate the apparent density in $\left(\mathrm{g} / \mathrm{cm}^{3}\right)$, where $W$ is the weight of the material in the cylinder $(\mathrm{g})$ and $V$ the volume occupied by the material in the measuring cylinder $\left(\mathrm{cm}^{3}\right)$.

$$
\text { Apparent density }=\frac{W}{V}
$$

\subsection{Thermal Properties}

The thermal properties of wood sawdust in its different granulometries were evaluated by thermogravimetric analysis (TGA) using Pyris 1 thermogravimetric analyzer from Perkin Elmer (Waltham, MA, USA). Experiments were performed in ceramic pans, at a heating rate of $10^{\circ} \mathrm{C} / \mathrm{min}$ from $30^{\circ} \mathrm{C}$ to $800{ }^{\circ} \mathrm{C}$ under nitrogen and artificial air atmospheres with a flow rate of $60 \mathrm{~mL} / \mathrm{min}$.

\subsection{Heat Treatment and Color Determination}

Wood sawdust of different granulometries were exposed to a heat treatment to evaluate its color change when exposed to high temperatures for a period of time. The temperature and time of exposure were selected according to the typical processing cycle of PE. Therefore, the samples were subjected to temperatures ranging from $170{ }^{\circ} \mathrm{C}$ to $230{ }^{\circ} \mathrm{C}$, with $10^{\circ} \mathrm{C}$ between them, in a Binder oven for 20, 30 and 40 min, respectively. Upon heat 
treatment the color was measured using a Spetro-guide BYK portable colorimeter (BYK Geretsried, Germany). The color parameters $L, a$ and $b$ were determined according to the CIELab method. The system is based on the measurement of three coordinates: lightness $L^{*}$ between 0 (black) and 100 (white), $a^{*}$ representing red-green levels (+60 red, -60 green) and $b^{*}$ representing yellow-blue levels ( +60 yellow, -60 blue). The color of a material is a mixture of these three parameters. The color variation was calculated according to Equation (2) [47], where $\Delta L, \Delta a$ and $\Delta b$ correspond, to the variation of the coordinates $L^{*}, a^{*}$ and $b^{*}$ relative to the reference samples. The reference sample was considered to be the wood sawdust after separation by granulometries.

$$
\Delta E=\sqrt{\Delta L^{2}+\Delta a^{2}+\Delta b^{2}}
$$

\subsection{Compounding of Materials and Processing of Parts}

In a first study regarding the effect of wood sawdust granulometries, MDPE was dry blended with wood (pre-dried in a Binder oven at $50{ }^{\circ} \mathrm{C}$ during $6 \mathrm{~h}$ ) in the proportions of $90 / 10$ and $70 / 30 \mathrm{wt} \%$, respectively and processed by rotational molding.

For the processing of the parts, a laboratory rotational molding equipment with characteristics of a Rock and Roll and Shuttle machines was used, with an aluminum mold with parallelepipedic dimensions of $140 \mathrm{~mm}$ length, $90 \mathrm{~mm}$ width, $90 \mathrm{~mm}$ height and $5 \mathrm{~mm}$ of mold wall thickness. This is a prototype machine developed at the Department of Polymer Engineering at the University of Minho [48]. In this type of machine, the mold rotates $360^{\circ}$ through the axis of the support arm and the oven performs a swinging motion of 45 degrees to the right and to the left perpendicular to the support arm, allowing the spreading of the material for the ends of the part. The rotation speed of the mold and the pendulum swing were $7 \mathrm{rpm}$ and $1.5 \mathrm{rpm}$, respectively. For each part, $200 \mathrm{~g}$ of material was used. The oven was heated by electrical resistances and set to $300^{\circ} \mathrm{C}$.

The internal air temperature (IAT) of the mold was monitored during processing by a thermocouple type $\mathrm{k}$ placed inside the mold through the vent conduct. Upon reaching the peak internal air temperature (PIAT) of $200{ }^{\circ} \mathrm{C}$, cooling by air was applied until the temperature inside the mold dropped to $60^{\circ} \mathrm{C}$ before demolding the part.

In a second part of the study, the effect of wood content on the composite material was evaluated at specific wood sawdust granulometries, namely, $<150,150-300$ and $300-500 \mu \mathrm{m}$. Therefore, MDPE was dry blended with different wood sawdust in the proportions of $90 / 10$, $85 / 15,80 / 20,75 / 25$ and $70 / 30 \mathrm{wt} \%$. The same conditions referred previously were applied for the processing of parts.

\subsection{Microscopy Analysis}

The wood sawdust and the impacted fractured WPC parts were analyzed by Scanning Electron Microscopy (SEM) using an Ultra-high-resolution Field Emission Gun Scanning Electron Microscope (FEG-SEM), NOVA 200 Nano SEM, FEI Company (Hillsboro, OR, USA). Secondary electron images were performed with an acceleration voltage of $10 \mathrm{kV}$. Prior to the analyses the samples were covered with a very thin film $(20 \mathrm{~nm})$ of $\mathrm{Au}-\mathrm{Pd}$ (80-20 wt\%), in a high-resolution sputter coater, 208HR Cressington Company (Watford, UK), coupled to a MTM-20 Cressington High Resolution Thickness Controller.

To image the part surfaces and defects, an Olympus SZ-PT stereoscopic magnifier (Olympus Corporation, Tokyo, Japan) was used. Surface preparation was not required.

The distribution of wood particles on the MDPE matrix was accessed by bright field microscopy and its influence on the morphology was obtained by polarized light microscopy. Both techniques used a transmission optical microscope Leica DM 2500 P (Wetzlar, Germany), coupled with a Leica Application Suite software (Wetzlar, Germany). Samples were prepared using a Leitz 1401 microtome (Wetzlar, Germany) equipped with a glass slicing knife; $15 \mu \mathrm{m}$ thick slices were cut along the thickness direction and placed between a microscope glass slide and cover glass. To prevent them from curling up or corrugating, Canada balm was used as a fixing resin. 


\subsection{Mechanical Tests}

The mechanical properties of the parts were determined by puncture impact tests, according to the standard ISO 6603-1:2000 and ISO 6603-2:2000 on a CEAST Fractovis Plus instrument falling weight impact tester (INSTRON CEAST, Pianezza, Italy). All the specimens were subjected to the same energy level (147.5 J), with an impact velocity of $4.4 \mathrm{~m} / \mathrm{s}$ resulting from a drop height of $1 \mathrm{~m}$ of a carriage of total mass of $15 \mathrm{~kg}$. The tested specimens were squared with $60 \mathrm{~mm}$ side. Eight specimens were tested for each sample.

A statistical analysis was performed using the one-way ANOVA (Analysis of Variance) to determine if differences existed between population means obtained for the same granulometry at different wood contents and for the same wood percentage considering different granulometries. The procedure tested the null hypothesis (Ho) that the average results are equal (suggesting that the incorporation of different wood percentages and different wood granulometries had no effect on the performance) against the alternative hypothesis ( $\mathrm{Ha})$ that at least one average result was different. A significance level of $5 \%$ was adopted for this study indicating that if the $p$-value of a statistical test was less than 0.05 , at least one of the population means was statistically different from the others and the null hypothesis (Ho) was rejected.

\subsection{Methodology Flow Chart}

Figure 2 represents a flow chart summarizing the methodology adopted for the execution of the experimental work. First, there is the characterization of the wood sawdust raw material upon being sieved in different granulometries; it follows the production of parts by rotational molding and the evaluation of wood granulometry and content on WPC properties. The work flow is set so that the relationship between materials characteristics, processing cycle, structure developed and final properties of wood/PE parts are achieved. The main goal is to identify the characteristics of natural materials that best suits the processing of WPC by rotational molding.

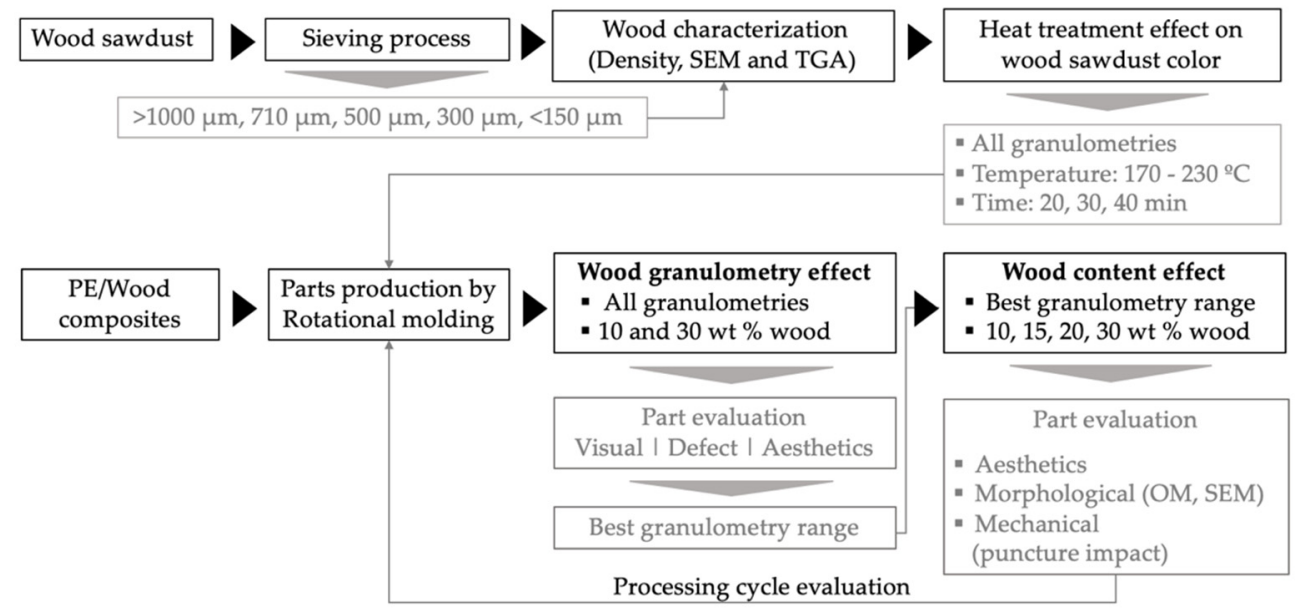

Best wood sawdust granulometry and composition for WPC

Figure 2. Flow chart summarizing the methodology followed for the work.

\section{Results and Discussion}

\subsection{Characterization of Raw Materials}

\subsubsection{Morphology of Virgin Wood}

Wood particles were imaged and depicted on Figure 3. The visual appearance of sieved wood (images on the left) resembles a powder for smaller granulometries and small wooden tapes or chips for granulometries greater than $500 \mu \mathrm{m}$. SEM images (on the right) shows very irregular wood particles and particles of different shapes and sizes according to their granulometry. The roughness and irregular shape are produced by the cutting and machining processes (sawing or grinding) of wood/timber and are observed 
in similar way in other published works [32]. Wood granulometries bellow $150 \mu \mathrm{m}$ (fine particles) are needle-shaped and can be found mostly as individual fibers in its longitudinal structure. With increasing of wood granulometry, particles tend to become a compact brick-shaped structure, with a multicellular structure typical of wood fibers (courser and oversized particles). A transversal lamellar structure is clearly observed in some images. According to Guo et al. [49] biomass materials are characterized by that due to the wood anisotropic structure.
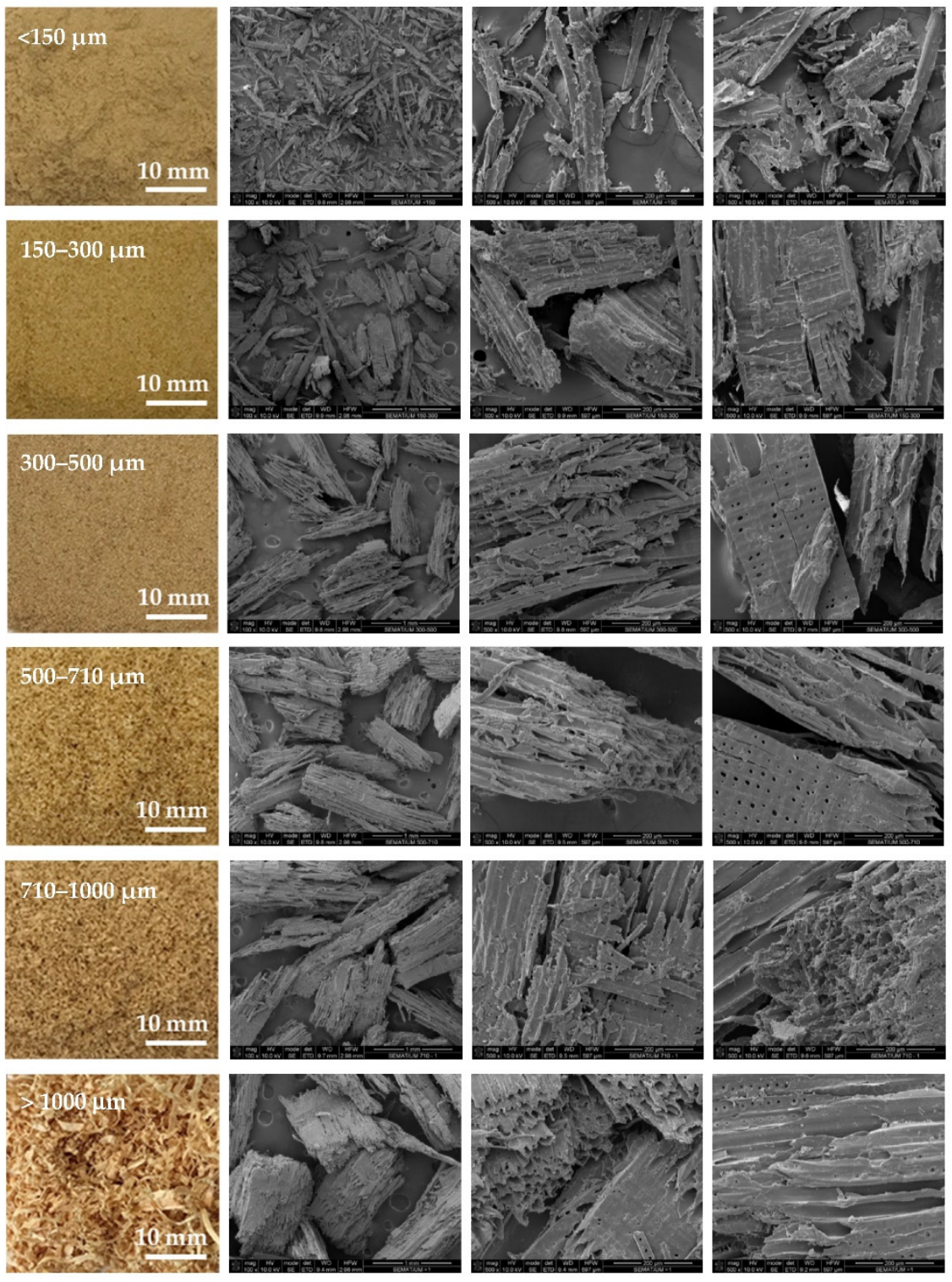

Figure 3. Images of wood sawdust according to its granulometry.

\subsubsection{Apparent Density of Wood Sawdust}

The apparent density of MDPE and wood sawdust with different granulometries are shown in Table 1. MDPE presents an apparent density of about $0.42 \mathrm{~g} / \mathrm{cm}^{3}$ which is in the characteristic range of this material [50]. Wood sawdust can vary between $0.22 \mathrm{~g} / \mathrm{cm}^{3}$ for fine particles size $(<150 \mu \mathrm{m})$, to $0.18-0.19$ for courser particles size $(150-1000 \mu \mathrm{m})$, and finally $0.08 \mathrm{~g} / \mathrm{cm}^{3}$ for oversized particles size $(>1000 \mu \mathrm{m})$. Large-size particles are less likely to pack together as they are ordinarily very bulky, therefore the apparent density is very low. The wood sawdust apparent density is about twice as low as that of MDPE $\left(0.42 \mathrm{~g} / \mathrm{cm}^{3}\right)$ which may cause difficulties during processing of WPCs by rotational molding. 
Table 1. Apparent density of MDPE and wood with different granulometries. Images correspond to $10 \mathrm{~g}$ of each material.

\begin{tabular}{|c|c|c|c|c|c|c|c|}
\hline \multirow[b]{2}{*}{ Granulometry $(\mu \mathrm{m})$} & \multirow{2}{*}{$\begin{array}{c}\text { MDPE } \\
<500\end{array}$} & \multicolumn{6}{|c|}{ Wood Sawdust } \\
\hline & & $<150$ & $150-300$ & $300-500$ & $500-710$ & 710-1000 & $>1000$ \\
\hline $\begin{array}{l}\text { Apparent Density } \\
\left(\mathrm{g} / \mathrm{cm}^{3}\right)\end{array}$ & 0.42 & 0.22 & 0.19 & 0.19 & 0.18 & 0.18 & 0.08 \\
\hline Powders & & & & & & & \\
\hline
\end{tabular}

\subsubsection{Thermal Analysis of Wood Sawdust}

Thermogravimetric analysis (TGA) was used to understand the thermo-degradation behavior of wood sawdust with different granulometries and to identify the temperatures at which the main chemical processes are occurring. TGA was carried under both nitrogen and artificial air atmospheres. The degradation of wood is dominated by the behavior of its three main components: hemicellulose, cellulose and lignin; the proportion of each component in the wood varies depending on the species [51]. The results of the thermogravimetric analysis (TGA) and the respective derivate (DTG) are shown in Figure 4. Relevant data from all materials are summarized in Table 2.
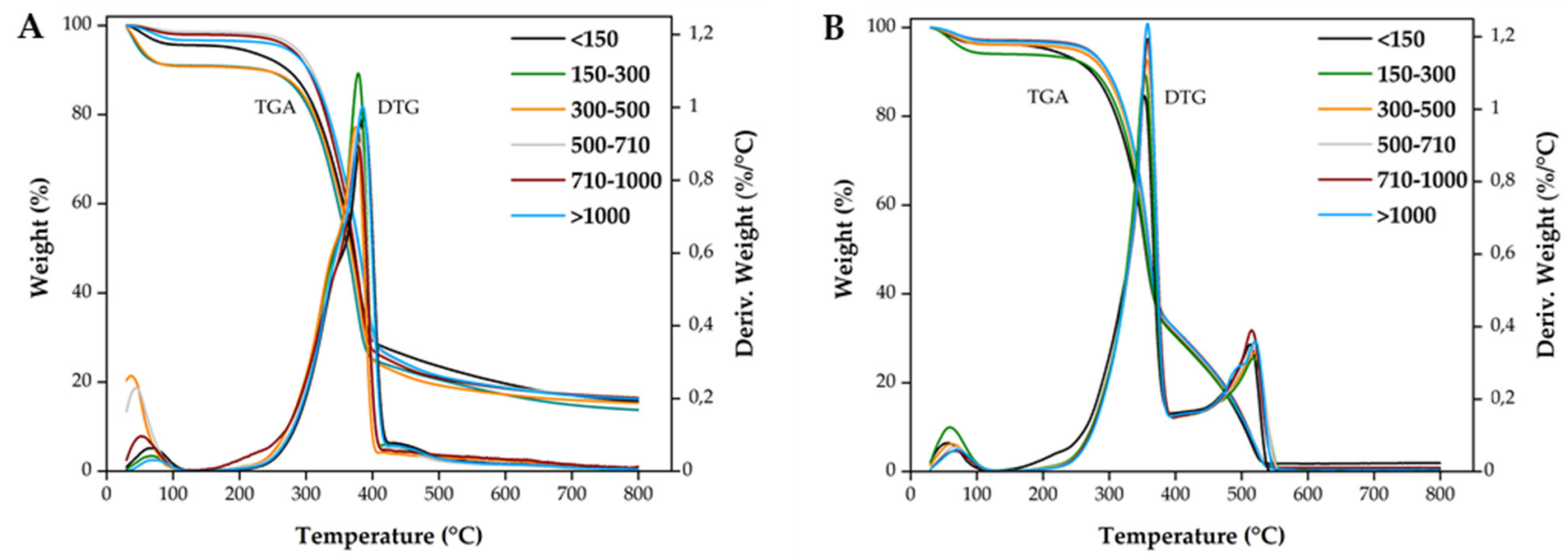

Figure 4. Thermal analysis (TGA) and derivative thermogravimetric analysis (DTG) curves of wood sawdust with different granulometries under: (A) nitrogen and (B) artificial air atmosphere.

Several regions can be identified in the thermogravimetric curves. Under a nitrogen atmosphere the wood sawdust shows an initial region of mass loss below $240^{\circ} \mathrm{C}$ corresponding to the elimination of water $\left(40-100^{\circ} \mathrm{C}\right)$ and a slight decomposition of hemicellulose (150-240 ${ }^{\circ} \mathrm{C}$ ). The maximum degradation of hemicellulose takes place at around $310{ }^{\circ} \mathrm{C}$, where a shoulder in the DTG curve appears [52]. Depending on the wood granulometry, the onset of decomposition was observed between $302-313^{\circ} \mathrm{C}$, in this study.

At around $366{ }^{\circ} \mathrm{C}$ the main degradation of cellulose occurs and a prominent peak appears at the temperature corresponding to the maximum decomposition rate. This behavior is similar to the literature for other wood species $[51,53]$. 
Table 2. Summary of TGA data for each wood granulometry.

\begin{tabular}{ccccccc}
\hline \multirow{2}{*}{$\begin{array}{c}\text { Granulometry } \\
(\boldsymbol{\mu m})\end{array}$} & \multicolumn{2}{c}{$\begin{array}{c}\text { Onset Temperature } \\
\text { of Decomposition }\left({ }^{\circ} \mathbf{C}\right)\end{array}$} & \multicolumn{2}{c}{$\begin{array}{c}\text { Temperature at Maximum } \\
\text { Decomposition Rate }\left({ }^{\circ} \mathbf{C}\right)\end{array}$} & \multicolumn{2}{c}{$\begin{array}{c}\text { Residue at } \\
\mathbf{8 0 0}{ }^{\circ} \mathbf{C}(\mathbf{\%})\end{array}$} \\
\hline & Nitrogen & Air & Nitrogen & Air & Nitrogen & Air \\
\hline$<150$ & 302.0 & 287.2 & 366.3 & 379.8 & 15.7 & 1.9 \\
$150-300$ & 317.2 & 295.7 & 366.1 & 373.5 & 13.7 & 0.6 \\
$300-500$ & 312.7 & 301.8 & 367.7 & 379.5 & 15.3 & 0.6 \\
$500-710$ & 311.5 & 305.7 & 368.5 & 385.7 & 16.6 & 0.5 \\
$710-1000$ & 313.5 & 308.3 & 368.2 & 379.2 & 16.4 & 0.9 \\
$>1000$ & 313.4 & 312.0 & 365.4 & 387.3 & 16.2 & 0.4 \\
\hline
\end{tabular}

Lignin is relatively more thermal stable when compared to hemicellulose and cellulose, which means this component contribute mainly to the shoulder above $400{ }^{\circ} \mathrm{C}$. Despite that, lignin degrades with increasing temperature, especially between $250^{\circ} \mathrm{C}$ and $500{ }^{\circ} \mathrm{C}$ [54]. Above $400{ }^{\circ} \mathrm{C}$, cellulose and hemicelluloses are already completely degraded. In the final region, around $500{ }^{\circ} \mathrm{C}$, the rate of mass loss lowers until the wood reduces to ashes. About $16 \%$ by weight was retained as residue.

TGA under artificial air atmosphere was also analyzed to understand the behavior of the material in a similar environment to that occurring inside the mold during processing (Figure 4B). After the elimination of water, there is a rapid mass loss between $200{ }^{\circ} \mathrm{C}$ and $390{ }^{\circ} \mathrm{C}$. The first peak, between $374^{\circ} \mathrm{C}$ and $387^{\circ} \mathrm{C}$ corresponds to degradation of polysaccharides composed of cellulose and hemicellulose that have degradation temperatures in the range between $300{ }^{\circ} \mathrm{C}$ and $400{ }^{\circ} \mathrm{C}$. The degradation of these two components form a single decomposition step [55]. Lignin is thermally more stable and contributes mainly to the second reaction $\left(512{ }^{\circ} \mathrm{C}\right.$ ) but oxidation of carbonaceous residues from previous degradation processes also takes through. In the final region, above $520^{\circ} \mathrm{C}$, all wood sawdust reduces to ashes and almost no residue is observed.

The results are suggesting that wood can be processed at temperatures typically used for the processing of polyethylene, between $170-230^{\circ} \mathrm{C}$, with no significant and irreversible changes in the wood chemical composition [52].

\subsubsection{Effect of Heat Treatment of Wood Sawdust}

Figure 5 depicts the images of wood sawdust before and after the heat treatment. Wood color presents a light brown color that darkens with increasing temperature and time. The perception of color change is significant for times above $30 \mathrm{~min}$ for higher temperatures (above $200^{\circ} \mathrm{C}$ ). The color variation was evaluated (Figure 6). When increasing the temperature at each time, the following was observed: for $<150 \mu \mathrm{m}$ samples, $\Delta E$ varied between (2.48-15.97) for $20 \mathrm{~min}$, and (3.64-23.83) for $40 \mathrm{~min}$; for 300-500 $\mu \mathrm{m}$ samples, $\Delta E$ ranged from (4.83-15.79) for $20 \mathrm{~min}$ to (7.17-33.03) for $40 \mathrm{~min}$; and for $>1 \mathrm{~mm}$ samples $\Delta E$ ranged between (2.48-11.76) for $20 \mathrm{~min}$ and (4.34-33.27) for $40 \mathrm{~min}$. All the values represent a significant color change of wood with heat treatment. However it seem that smaller wood particles are more sensitive to color change at shorter times and less sensitive as the time evolves; the opposite seems to occur for larger size particles. These results show a dependency of wood granulometry on its colour upon heat treatment.

According to Bekhta and Niemz [47], Kučerová et al. [56] and Akkuş and Budakçı [57], the darkening of wood is one of the most visible effects of heat treatment and its intensity depends on the severity of the treatment. This effect is often explained as the result of the formation of colored degradation and oxidation products from hemicelluloses and extractives. It is also stated that heat treatment influences the surface color of different woods and this phenomenon is probably related to the volatilization of color extracts as well as to the oxidation of some chemical constituents of wood, including lignin and polysaccharides. Natural materials are prone to color change as a consequence of initial degradation effect, but not affecting the structural ability of the filler $[45,47,56,57]$. 


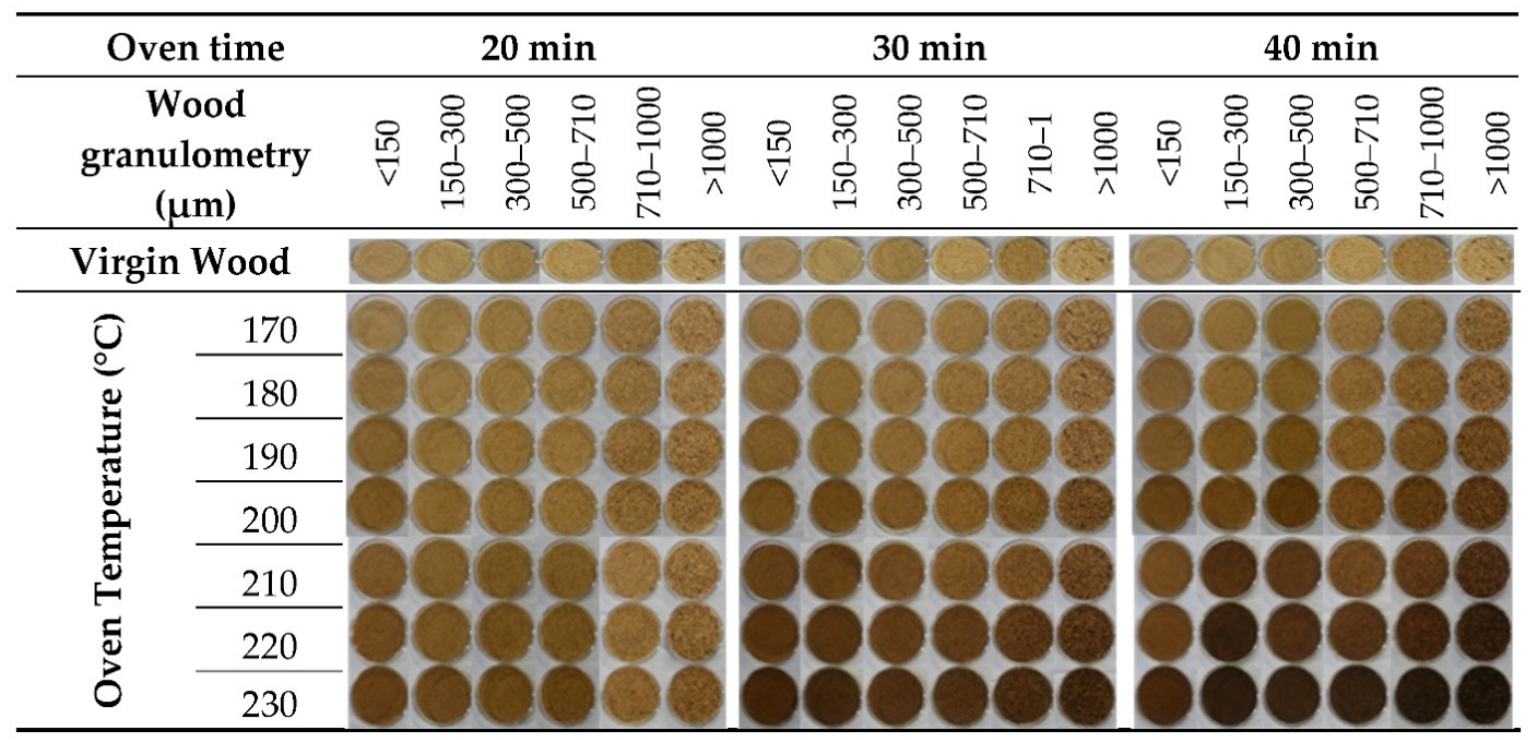

Figure 5. Effect of heat treatment conditions on the color of wood with different granulometries.
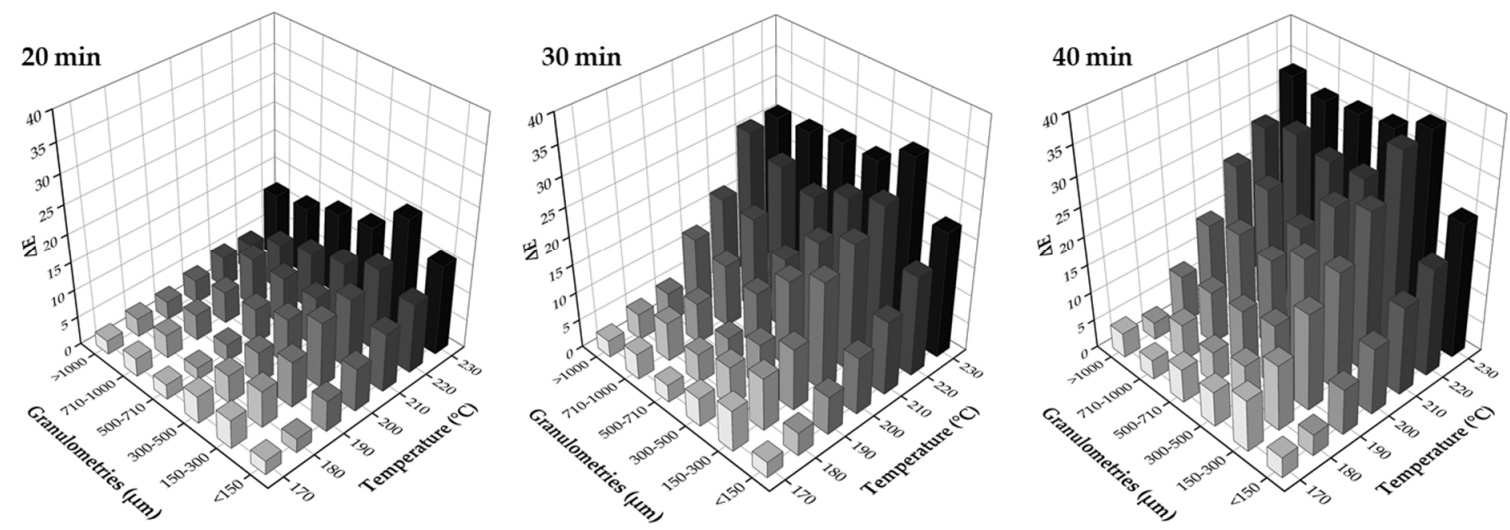

Figure 6. Color variation of wood particles with different granulometries, as a function of temperature and time.

The characterization of wood sawdust exposed the differences on the size and shapes of wood particles from needle (fine particles) to brick-shaped structures (courser particles). Their apparent density $\left(0.22-0.18 \mathrm{~g} / \mathrm{cm}^{3}\right)$ is lower than PE $\left(0.42 \mathrm{~g} / \mathrm{cm}^{3}\right)$ and even more for oversized wood particles $\left(0.08 \mathrm{~g} / \mathrm{cm}^{3}\right)$. The color of wood changes when exposed to heat treatment at high temperatures and times. These characteristics may result in difficulties on the sintering of WPC during rotational molding and the formation of parts with wood color degradation (darkening) as a result of oxidation products from hemicelluloses and extractives, occurring between 150 to $240{ }^{\circ} \mathrm{C}$, that is within the range of processing window of PE.

\subsection{Production of Parts by Rotational Molding}

\subsubsection{Evaluation of Processing Cycle}

Figure 7 presents the processing cycle curve of rotomolded parts, by depicting the oven temperature and the internal air temperature of the mold (IAT) as a function of time. In all cases, although the setup oven temperature was defined for $300^{\circ} \mathrm{C}$, the maximum oven temperature reached was $287^{\circ} \mathrm{C}$. The internal air temperature of the mold shows a typical curve, with a rapid increase in the temperature followed by a plateau observed between 120 and $160{ }^{\circ} \mathrm{C}$, which represents the moment of melting and adhesion of the PE/wood to the mold surface. The presence of natural fibers causes a delaying effect on plastic particle 
coalesce during the sintering process, as observed in the plot [58]. When the cooking stage is completed and PIAT is reached (setup at $200{ }^{\circ} \mathrm{C}$ ) the mold is transferred to the cooling chamber; the temperature drops and a small plateau occurs due to the crystallization of PE. It follows the solidification of the material until the part is demolded.

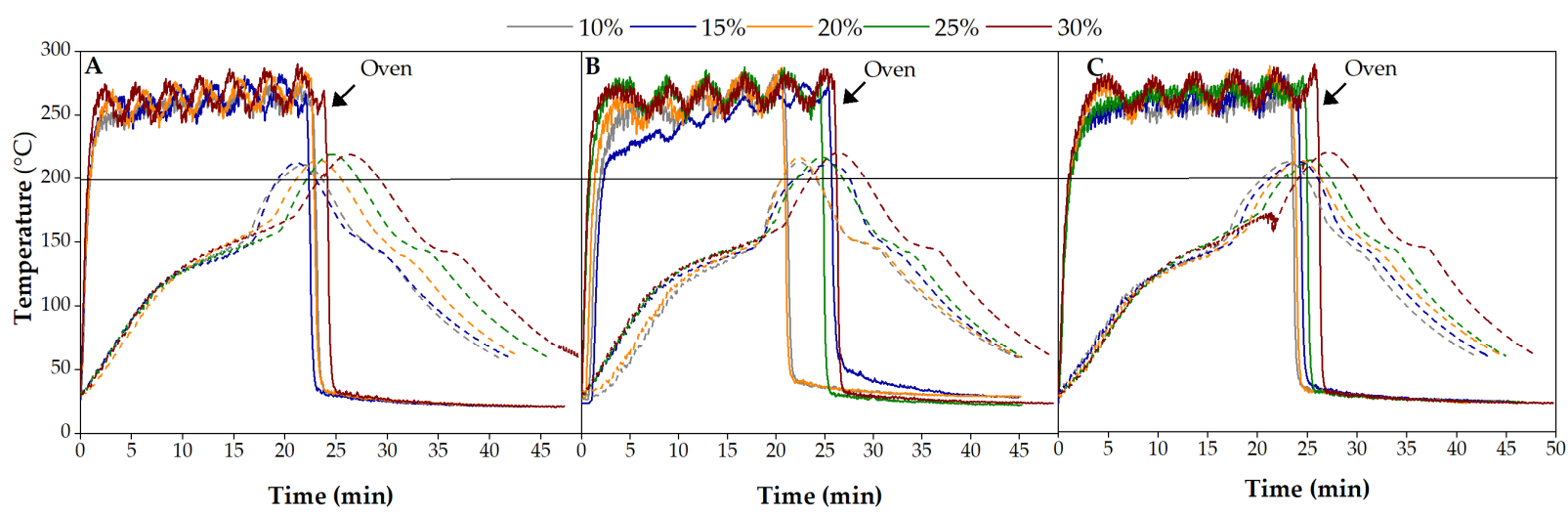

Figure 7. Oven and mold internal air temperature profiles during the processing cycle of MDPE/wood composites by rotational molding. Effect of wood content and its granulometry: (A) $<150 \mu \mathrm{m}$; (B) 150-300 $\mu \mathrm{m}$ and (C) 300-500 $\mu \mathrm{m}$.

During processing cycle an overshooting of PIAT is observed that is related to the presence of wood on the composite (a line is depicted at setup PIAT, $200{ }^{\circ} \mathrm{C}$ ). The heat transferred from the mold to the particles is delayed and becomes trapped inside the mold during cooling, leading to an overshooting of PIAT and longer cycle times. The higher the wood content on the composite, the greater is its effect on the cycle time. Moreover, a color change on the part is observed, as the material is inside the mold for about $20 \mathrm{~min}$ at temperatures between $170{ }^{\circ} \mathrm{C}$ and $225^{\circ} \mathrm{C}$ (real PIAT). The color of the part is darker for granulometries $<150$ and $150-300 \mu \mathrm{m}$ than for 300-500 $\mu \mathrm{m}$ and above (Table 3), following the same trend observed on the heat treatment studies. Related results were observed in previous studies in PE/cork composites [45].

Table 3. Images of parts produced by MDPE/wood composites using 10 and 30\% of each wood granulometry.

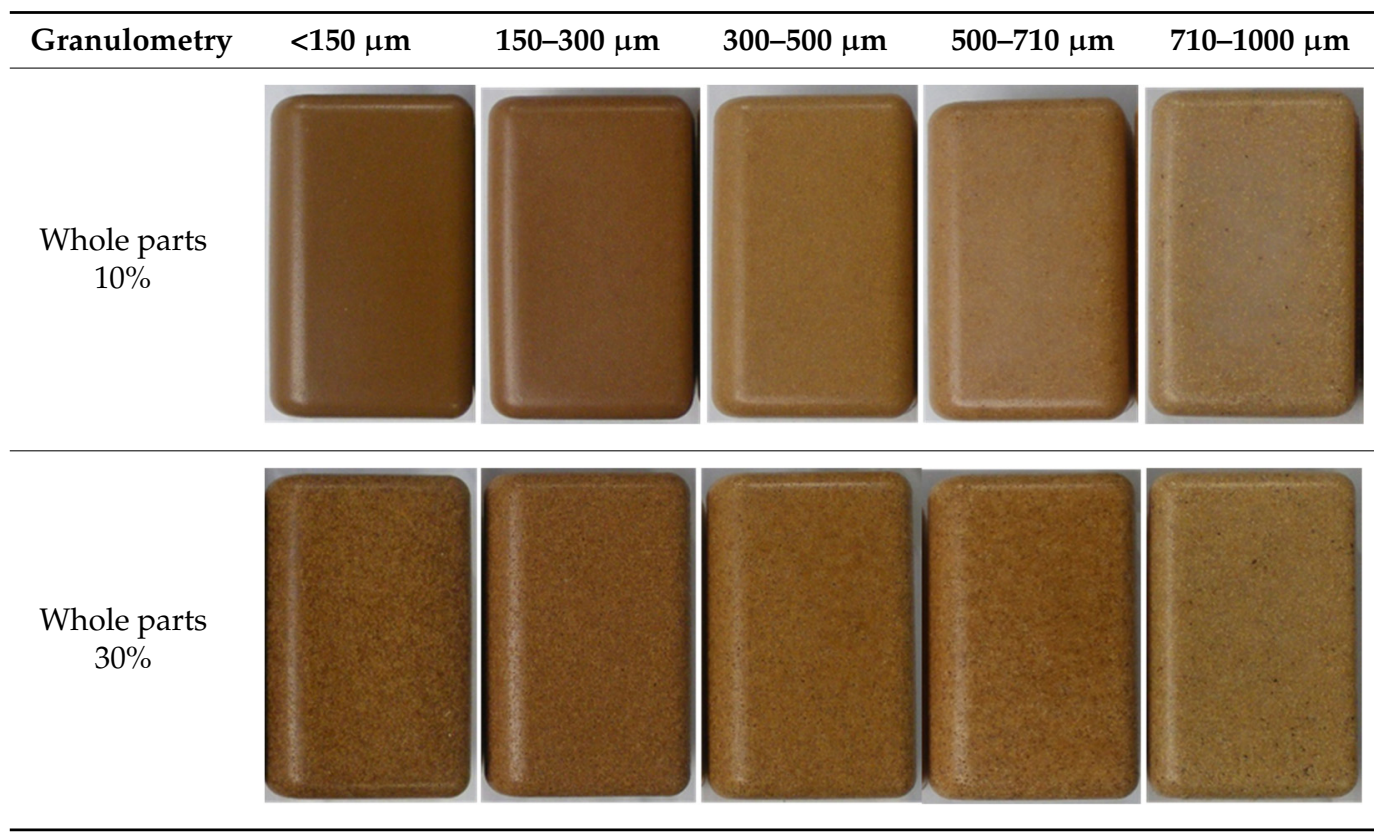




\subsubsection{Effect of Wood Sawdust Granulometry}

Table 3 depicts the appearance of rotomolded parts produced with different wood granulometries and compositions (10 and $30 \mathrm{wt} \%$ ). Parts of good quality were obtained; different colors and textures were achieved depending on the granulometry used. Parts produced with fine particles were darker in color, following the same tendency observed in the heat treatment studies. Moreover, when increasing the wood content to $30 \mathrm{wt} \%$, parts were no longer homogeneous in its color and a color texture appeared.

The increase in wood granulometry resulted in the reduction of the sintering capability of the composite increasing its porosity, wall thickness and surface defects. Some defects are illustrated in Table 4 for reference. Parts processed with 500-710 $\mu \mathrm{m}$ and $710-1000 \mu \mathrm{m}$ have a plastic shiny look, plastic touch and milky surface in some regions, resulting from the presence of PE on the outer layer. Furthermore, the increase in wood content resulted in the appearance of defects such as pinholes, heterogeneous surface, surface roughness and visible wood particles.

Table 4. Main defects of parts produced with MDPE/wood composites with large wood granulome-

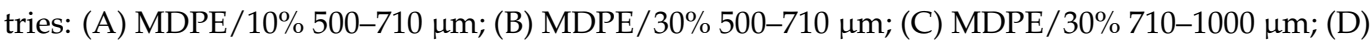
and (E) MDPE $/ 10 \%>1 \mathrm{~mm}$.

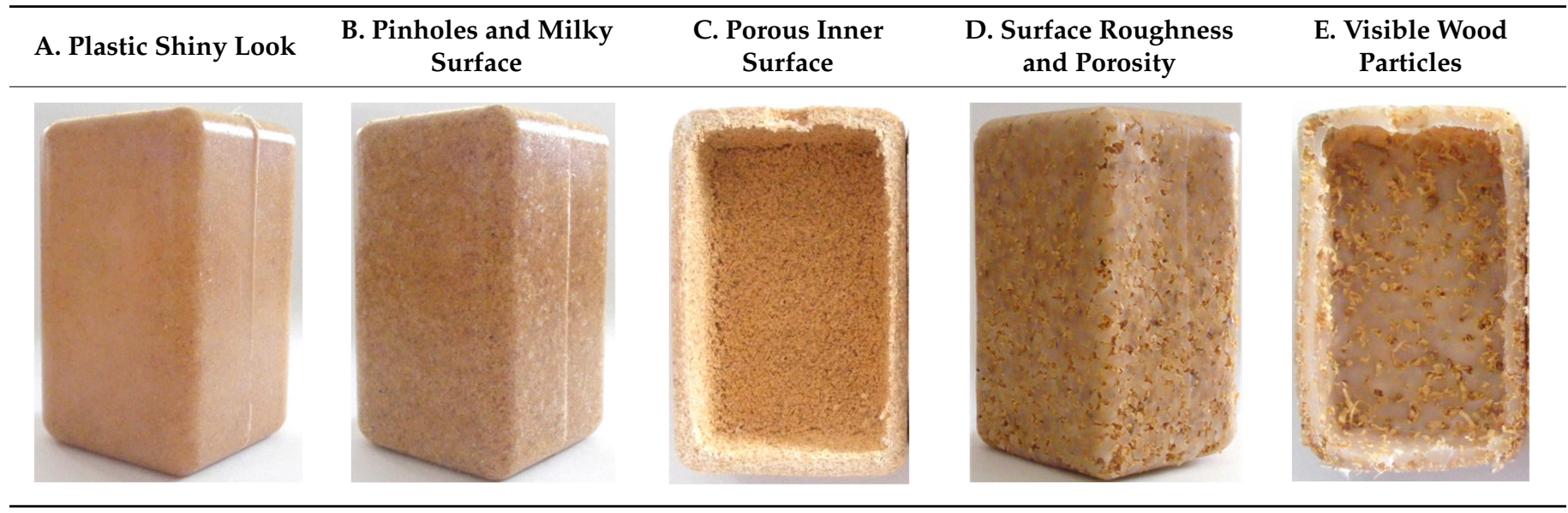

These results are in good agreement with a very recent work of ArribasplataSeguin et al. [32] that have studied in great detail the sintering process of parts by rotational molding when varying the processing conditions applied (oven temperature and time) and the wood particles size of untreated capirona and pine wood. They showed that irregular surfaces can be obtained by the lack of sintering time, low temperatures or large wood granulometries. Therefore, the sintering process develops more efficiently as wood particles size decreases or the oven temperature and heating time increases.

Torres and Aguirre [31] also showed a tendency for the natural fibers to remain in the inner surface of the molded part, as observed in Table 4, image (C) and (E). To solve this problem, it is suggested to add a second layer of unreinforced polymer that covers and sinters on the inner surface to produce an inner smooth surface.

Particles larger than $1 \mathrm{~mm}$ were excluded from the study, since they presented a nonhomogeneous color, numerous voids, lack of wood/polymer wetting and adhesion, and loose wood material inside the part. These results may be explained by the great difference in the apparent density of the materials, which translates into very poor sintering and the appearance of defective parts.

It is important to notice that color of parts is greatly dependent on the processing cycle of each part; thus, it is expectable to observe some color variation on the reproduction of parts. The parts with better appearance, look and touch, that revealed some similarity to 
wood sawdust were those with granulometries of $<150 \mu \mathrm{m}, 150-300 \mu \mathrm{m}$ and 300-500 $\mu \mathrm{m}$. Therefore, the studies that follows were carried only with these wood granulometries.

\subsubsection{Effect of Wood Content on Part Quality}

The wood content has a major effect on the part's final appearance. As observed in Table 5, there is a change from homogeneous brown color at low wood weight percentages (10 and $15 \%$ ) to a color texture above $20 \%$.

Table 5. Images of parts produced by MDPE/wood composites with 10, 15, 20, 25 and 30\% wood content, for $<150 \mu \mathrm{m}, 150-300 \mu \mathrm{m}$ and 300-500 $\mu \mathrm{m}$ wood granulometries.

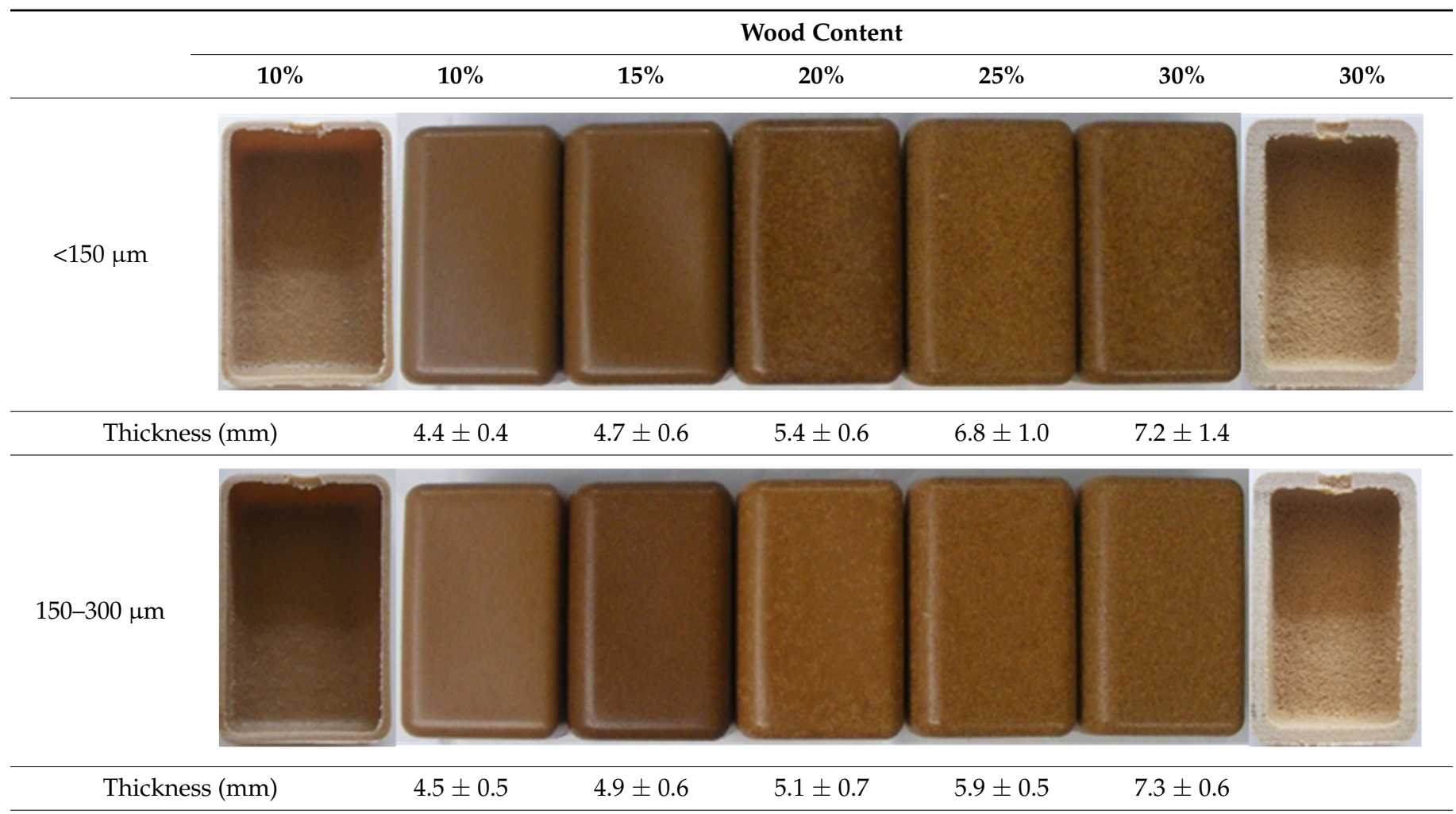

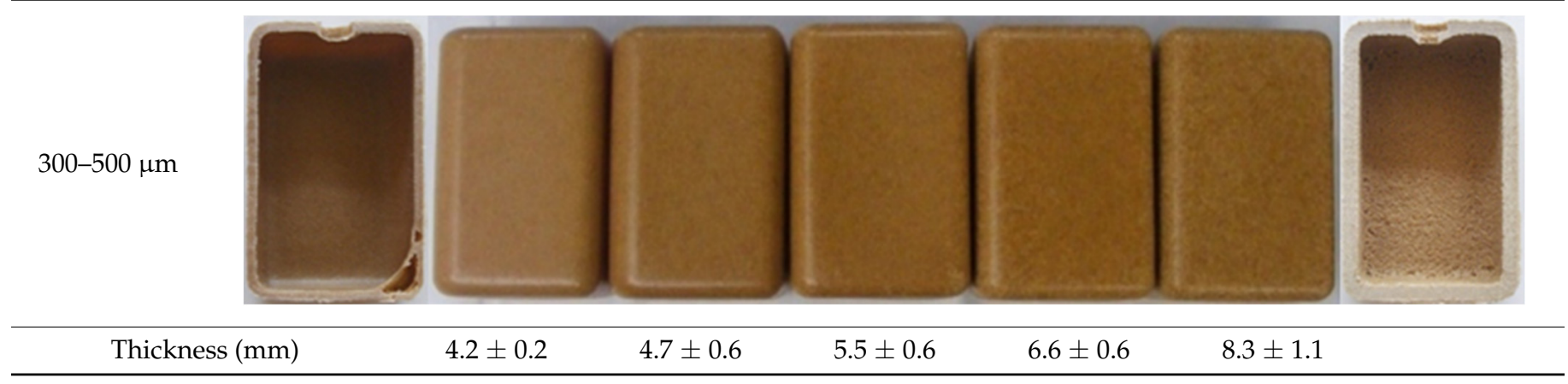

The major reason for that seems to be the inability of polymer to create a uniform and smoother layer at the outer surface by the presence of wood particles (Table 6). The adhesion between plastic particles begin much earlier in WPC that contain lower quantities of wood (up to $15 \%$ ). For those, a smooth external surface with roughness identical to PE is obtained. Surface defects are more abundant at high wood contents, such as pinholes and surface roughness. Therefore, they change the way light is reflected on the sample surface, giving the sensation of a color change, tint or shade. The internal surface also becomes rough with increase of wood content and its granulometry, since no enough polymer is available to wet all the wood particles (Table 6) [32]. The inability of the WPC to compact properly, as rotational molding process is unable to provide that due to absence of any 
shear stresses during the processing cycle [32], causes the thickness of the part to increase significantly (results summarized in Table 5). Rotational molding is prone to have voids along the thickness direction due to air trapped during cooling, that could be enhanced with wood natural moisture [27]. However, according to Ward-Perron et al. most of the humidity evaporates before the polymer starts melting and sticks to the mold walls, resulting in its elimination before the end of rotational molding heating cycle [59]. Hence, the porosity observed is the result of high wood contents and lack of good sintering of materials, as plastic particles are unable to wet wood properly [32].

Table 6. Effect of wood granulometry and wood content on the surface characteristics of PE/wood parts.

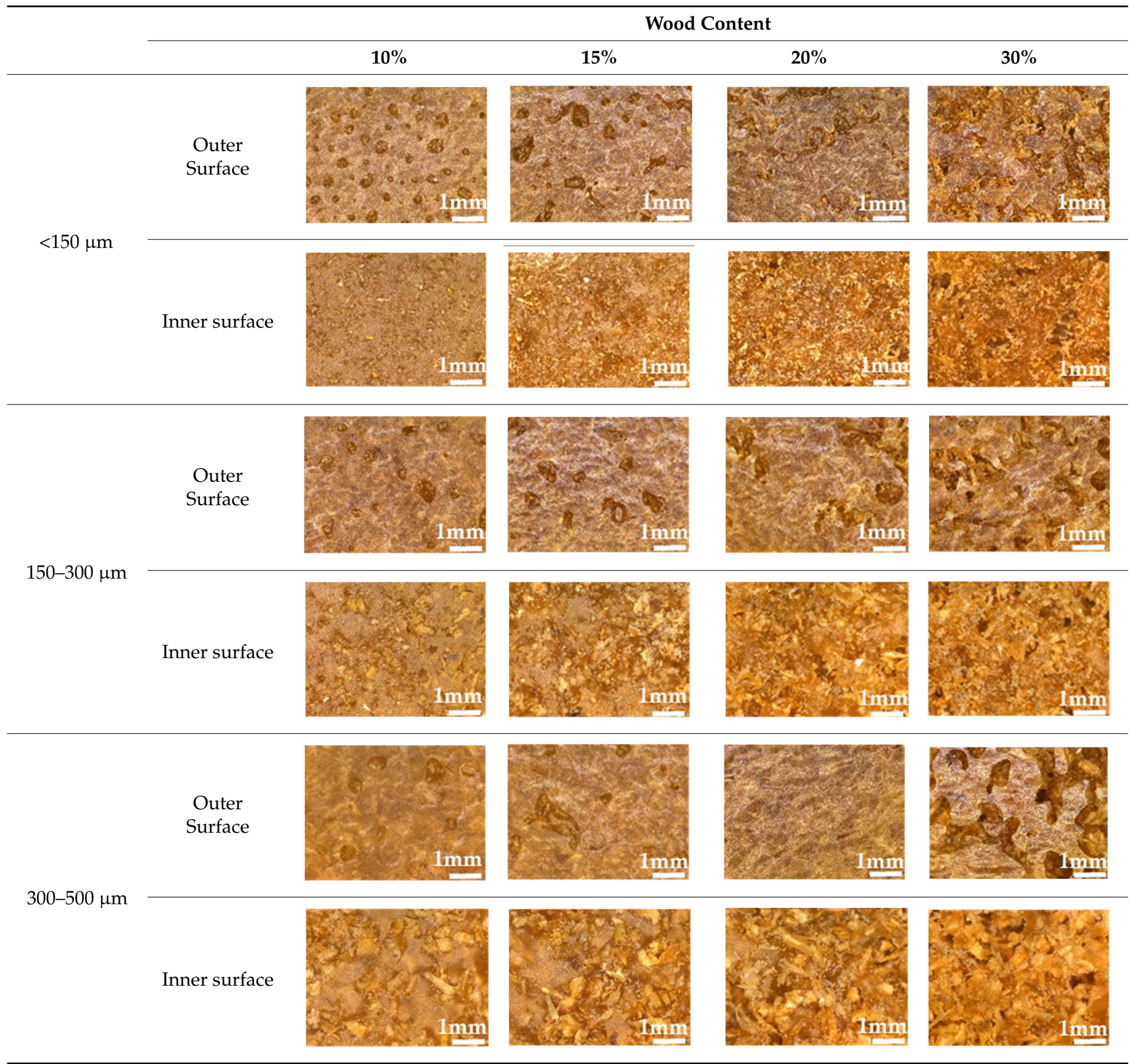

The production of WPC parts reveals the importance of wood granulometry and wood content on the part quality. WPC processed well at temperatures used for PE, however the large cycle time applied at high temperatures caused some wood color darkening. Wood granulometries bellow $500 \mu \mathrm{m}$ resulted in parts of good quality, brown in color and with 
good aesthetic appeal; 500 to $1000 \mu \mathrm{m}$ resulted in defective parts, namely, plastic touch and shiny look, inhomogeneous surfaces and visible wood particles. The wood content played an important role on color; up to $15 \%$ a homogeneous brown color was obtained and above $20 \%$ color texture appeared. Surface defects were more abundant at high wood contents, such as pinholes and surface roughness, due to WPC sintering difficulties.

\subsection{Characterization of Rotomolded Parts \\ 3.3.1. Morphology of Parts}

Optical microscopy images of PE/10 wt\% wood parts with 150 and 300-500 $\mu \mathrm{m}$ are depicted in Figure 8. Difficulties on cutting samples containing larger wood contents made unfeasible to illustrate them. Wood particles are well distributed on the polymer matrix, being clear the difference between wood granulometries on each case. No agglomerates are observed. Heterogeneities on the wood sizes and shapes are expected, from the characteristics of the virgin wood material. The morphology of PE is characterized by a very small and uniform spherulitic structure, which seems to indicate that wood has no effect on the crystallization behavior of PE. Some voids are observed, that are common in rotational molding products [27].

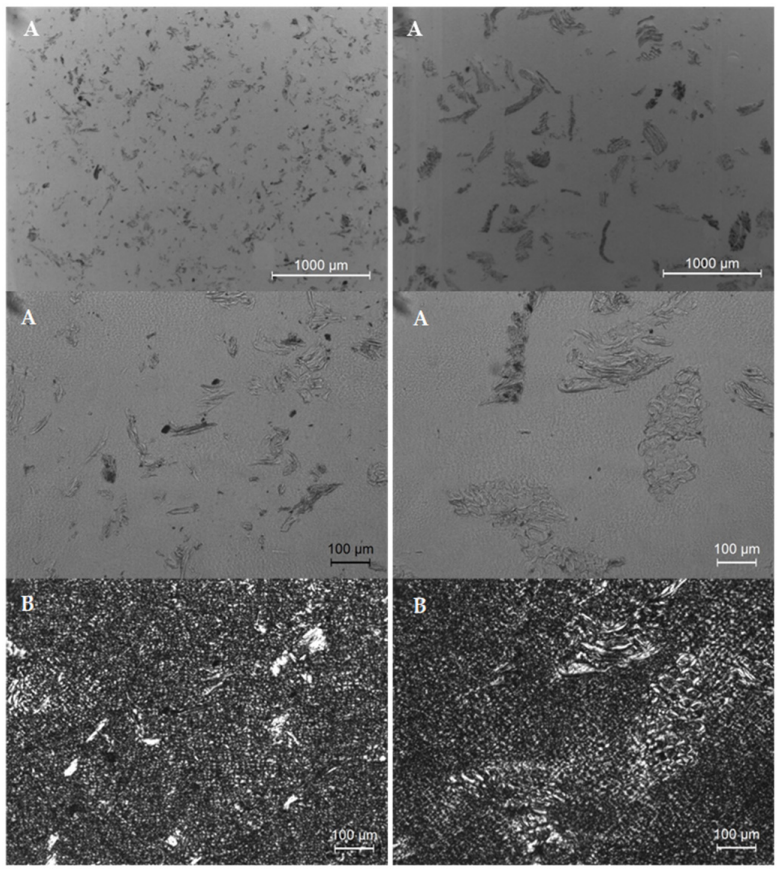

Figure 8. Optical microscopy images of MDPE/10 $\mathrm{wt} \%$ wood with granulometries of $<150 \mu \mathrm{m}$ (images on the left) and 300-500 $\mu \mathrm{m}$ (images on the right), obtained by (A) bright field microscopy and (B) polarized light microscopy.

SEM images (Figure 9) show wood particles well distributed on the matrix, regardless of the wood granulometry used. Fibers are very abundant in the case of wood granulometry $<150 \mu \mathrm{m}$ given their size compared to the other two cases, where it is easily seen the PE matrix and its ductile facture (Figures 9 and 10). The increase of wood content causes the increase of porosity on the matrix; the appearance of single fibers or small fiber bundles pullout from the matrix and the observation of wood bundles that are poorly wet by the polymer. These results illustrate well the difficulties on sintering the PE/wood parts when high wood contents are used (Figures 9D-F and 11D,E). Despite the weak interfacial strength between the wood and the matrix, the irregular shape of wood bundles or brickshape wood, results in the mechanical anchoring of the wood to the matrix, as observed in Figure 11. 

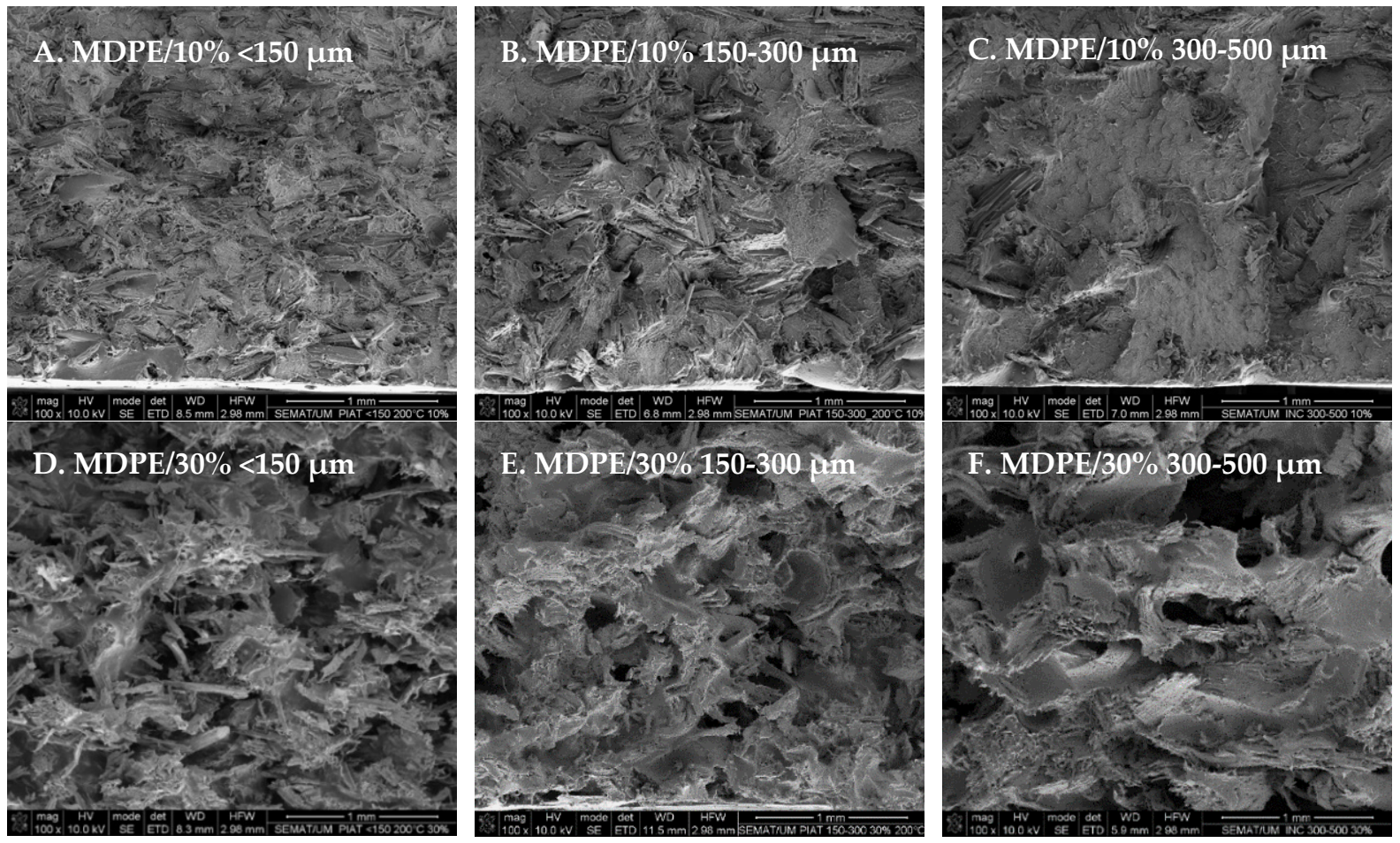

Figure 9. Effect of wood granulometry and wood content on the morphology of MDPE/wood composites.
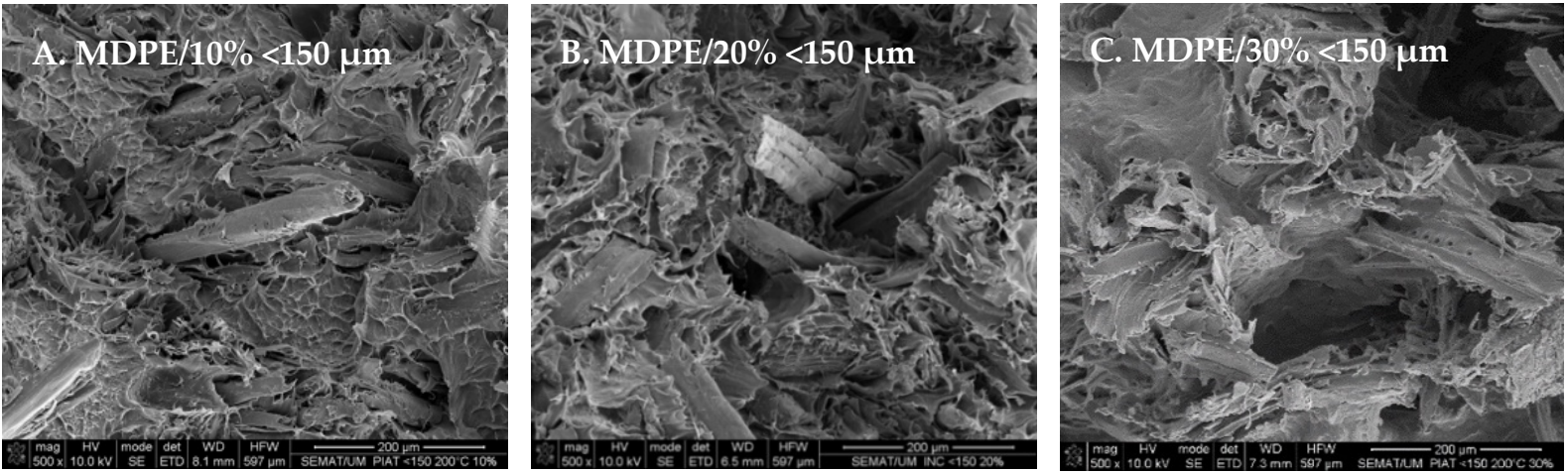

Figure 10. Effect of wood content on the morphology of MDPE/wood composites, with wood granulometry of $<150 \mu \mathrm{m}$.
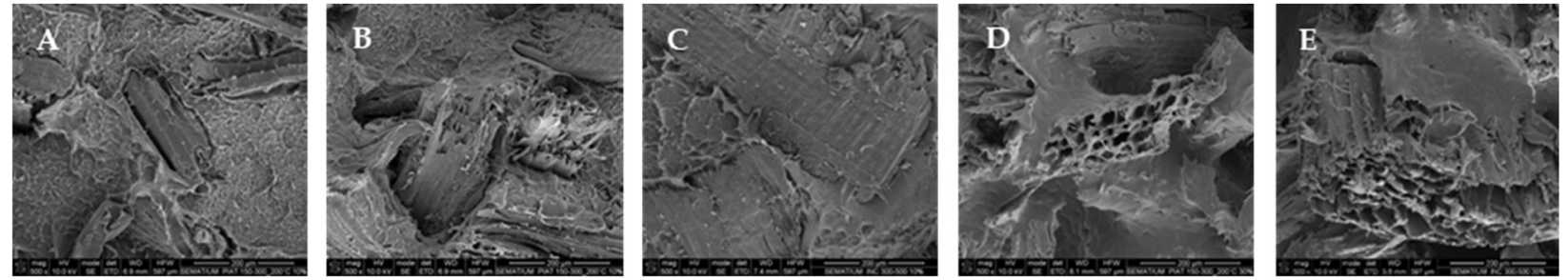

Figure 11. Morphological details of MDPE/wood composites. From left to the right: (A) fiber mechanically anchored to the matrix (MDPE/10\% 150-300 $\mu \mathrm{m}) ;(\mathbf{A}, \mathbf{B})$ lack of interfacial adhesion of wood to polymer (MDPE/10\% 150-300 $\mu \mathrm{m}$ ); (C) fiber on its transversal direction embodied on the polymer (MDPE / 10\% 300-500 $\mu \mathrm{m}$ ); (D) wood bundle well embodied on the polymer surrounded by large voids (MDPE/30\% 150-300 $\mu \mathrm{m}$ ); (E) wood bundle poorly wet by the polymer (MDPE/30\% 300-500 $\mu \mathrm{m})$. 


\subsubsection{Mechanical Properties of Parts}

Figure 12 depicts the mechanical impact behavior of the composite materials as a function of wood granulometry (Figure 12A,B) and the percentage of wood content (Figure 12C,D). The force and the energy to maximum force as a function deflection are shown together with the fracture surfaces of the parts. All parts suffer a failure by yielding followed by crack growth.
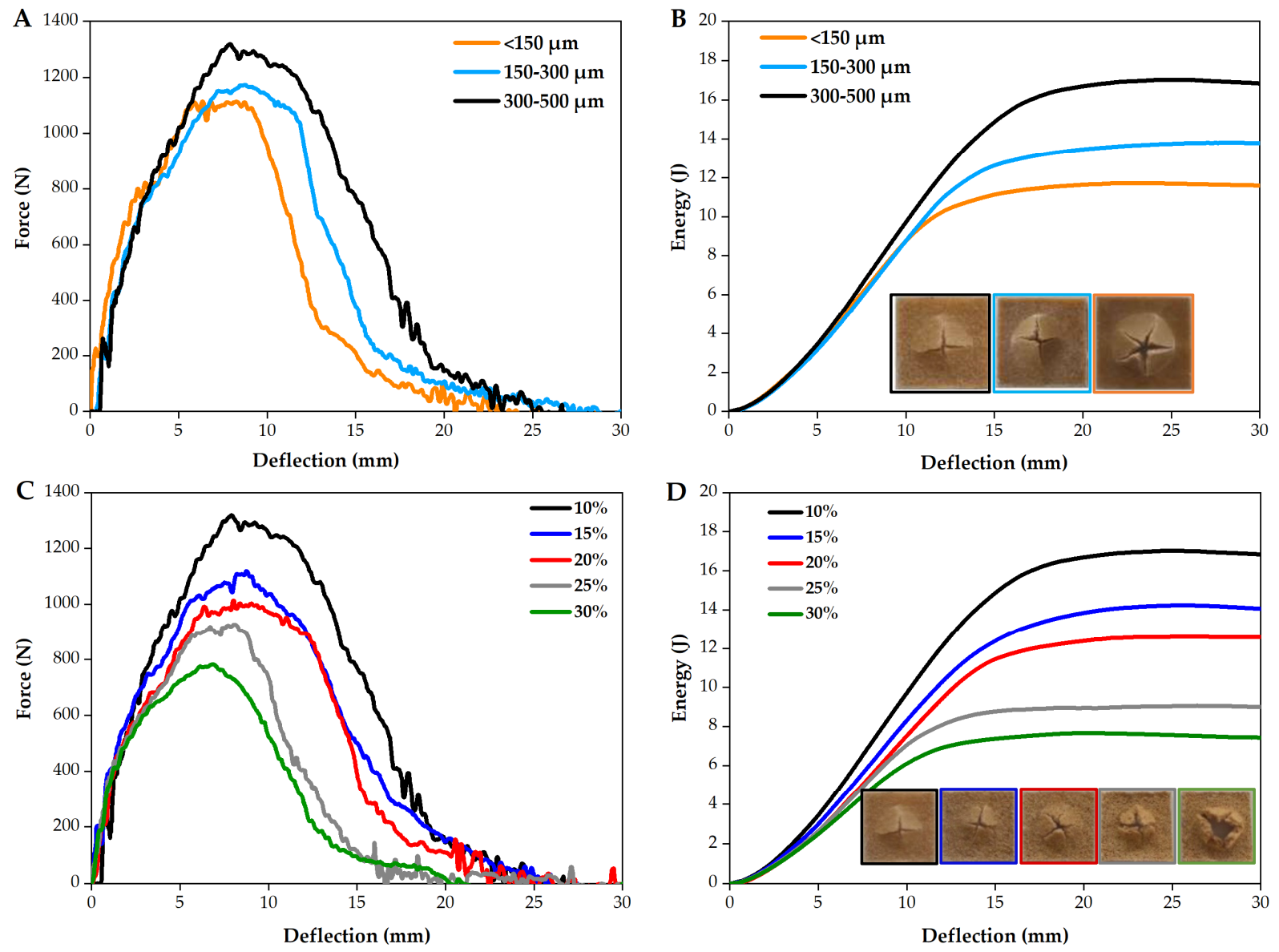

Figure 12. Force-deflection curve and energy-deflection curve of PE/wood as a function of wood granulometry (A,B) for parts with $10 \%$ wood and (C,D) wood content for parts processed with 300-500 $\mu \mathrm{m}$ wood.

These results are analyzed in Figure 13. The increase of wood granulometry, increases the force needed to yield to a fracture, whereas the increase of wood content decreases it. The same tendencies are observed for the energy at maximum force. The results may present a large standard deviation indicating the heterogeneity of the composites obtained upon processing. 

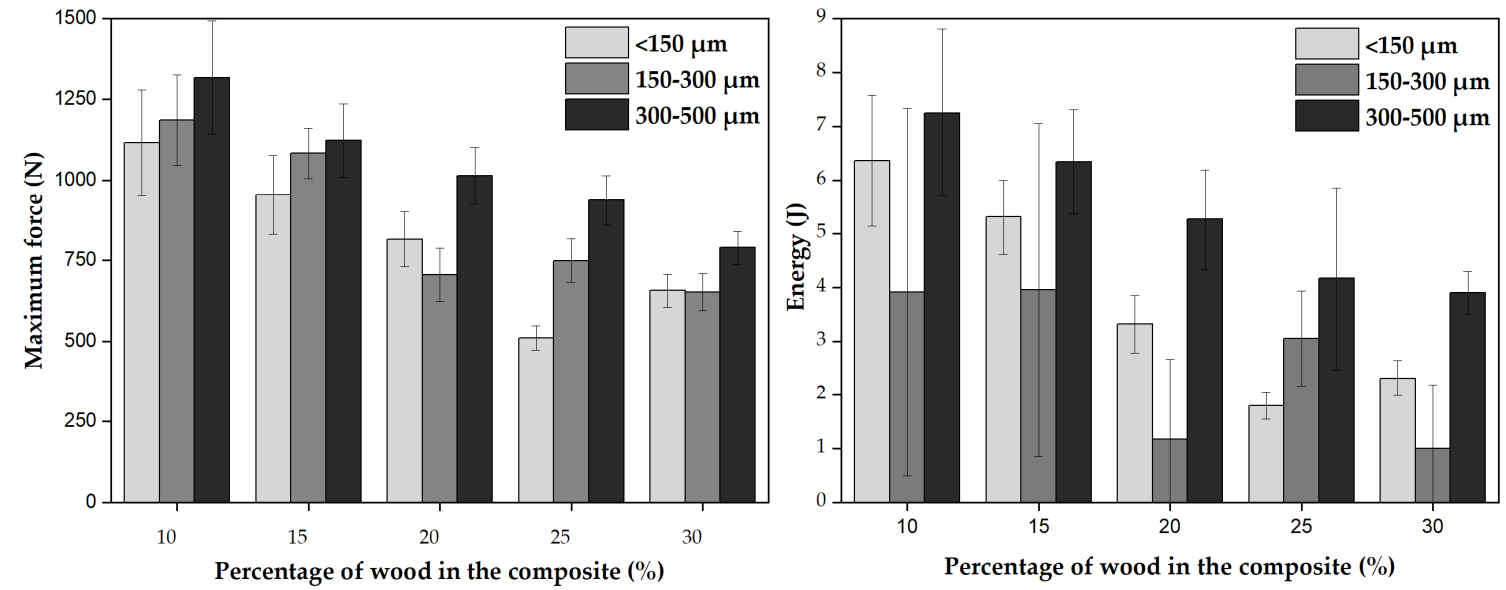

Figure 13. Effect of wood content and granulometry on the mechanical impact properties of MDPE/wood parts, namely, maximum force and energy to maximum force.

ANOVA results are presented in Tables 7 and 8, respectively for the force and energy. The nule hypotheses is rejected in most of the conditions which shows that the population means studied are statistically different. With the exception on two cases, namely, the force for parts with $10 \%$ wood and the energy for parts with $15 \%$ wood, as they have $p$-value $>0.05$.

Table 7. One-way ANOVA for comparison of the population means regarding the maximum force.

\begin{tabular}{cccccccc}
\hline & \multicolumn{7}{c}{ Mean Maximum Force (N) } \\
\hline & $\mathbf{1 0} \%$ & $\mathbf{1 5 \%}$ & $\mathbf{2 0} \%$ & $\mathbf{2 5 \%}$ & $\mathbf{3 0 \%}$ & F Value & $p$-Value \\
\hline$<150 \mu \mathrm{m}$ & 1115.4 & 9547.3 & 815.2 & 509.9 & 656.6 & 37.5 & $3 \times 10^{-12}$ \\
\hline $150-300 \mu \mathrm{m}$ & 1186.4 & 1083.2 & 705.5 & 749.3 & 652.2 & 51.0 & $4 \times 10^{-14}$ \\
\hline $300-500 \mu \mathrm{m}$ & 1317.0 & 1122.3 & 1013.2 & 936.6 & 789.0 & 23.1 & $2 \times 10^{-9}$ \\
\hline F value & 2.9 & 4.8 & 23.4 & 81.0 & 14.9 & \\
\hline$p$-value & 0.080 & 0.019 & $4 \times 10^{-6}$ & $1 \times 10^{-10}$ & $9 \times 10^{-5}$ & \\
\hline
\end{tabular}

Table 8. One-way ANOVA for comparison of the population means regarding the energy at maximum force.

\begin{tabular}{cccccccc}
\hline & \multicolumn{7}{c}{ Mean Energy (J) } \\
\hline & $\mathbf{1 0 \%}$ & $\mathbf{1 5 \%}$ & $\mathbf{2 0 \%}$ & $\mathbf{2 5 \%}$ & $\mathbf{3 0} \%$ & F Value & $p$-Value \\
\hline$<150 \mu \mathrm{m}$ & 6.4 & 5.3 & 3.3 & 1.8 & 2.3 & 55.3 & $1 \times 10^{-14}$ \\
\hline $150-300 \mu \mathrm{m}$ & 3.9 & 3.9 & 1.2 & 3.1 & 1.0 & 2.8 & 0.039 \\
\hline $300-500 \mu \mathrm{m}$ & 7.2 & 6,3 & 5.3 & 4.2 & 3.9 & 10.1 & $1 \times 10^{-5}$ \\
\hline F value & 4.0 & 2.7 & 25.8 & 8.0 & 14.9 & \\
\hline$p$-value & 0.034 & 0.089 & $2 \times 10^{-6}$ & 0.003 & $9 \times 10^{-5}$ & \\
\hline
\end{tabular}

According to the morphological studies, larger particles with irregular brick-shape, have better mechanical anchoring to the polymeric matrix, leading to improved mechanical properties as compared to small particles. These results are in good agreement with Dikone and Luyt [60] and Hanana et al. [37]. Regarding the effect of wood content, it is clear that low wood contents have a positive effect on the composite impact behavior. The impact force required to fracture a PE/300-500 $\mu \mathrm{m}$ wood sample reduces by $40 \%$ from $10 \mathrm{wt} \%(1316 \mathrm{~N})$ to $30 \mathrm{wt} \%(789 \mathrm{~N})$. This tendency is related to the lack of wettability and adhesion between materials as observed previously and also by other authors [32]. The 
presence of voids and porous structure due to poor sintering of material contributes to stress concentration points and a weak ability to transfer energy between them, causing the failure of the composites and composites with lower mechanical properties $[37,61]$.

In conclusion, parts with $10 \%$ of wood particles, regardless of their size (according to ANOVA results) seem to be the best combination to get the higher mechanical properties in MDPE/wood composites, processed by rotational molding. For mechanical impact forces up to $1000 \mathrm{~N}$, it is possible to consider composites containing up to $20 \mathrm{wt} \%$ of wood in its composition, but in this case, aesthetics of the part may be affected as reported earlier. These results are in good agreement with Cisneros-Lopez et al. [33] and Hanana et al. [44]. The study also shows that particle granulometries of 300-500 $\mu \mathrm{m}$ are those presenting the best properties among all particle's sizes studied.

\section{Conclusions}

The polyethylene wood sawdust composites produced by rotational molding were investigated. The effect of wood granulometry $(<150,150-300,300-500,500-710,710-1000$, $>1000 \mu \mathrm{m})$ and wood composition (10-20-30 $\mathrm{wt} \%)$, on the processing and properties of $\mathrm{PE} /$ wood composites were analyzed. Parts of good quality with a natural wood appearance, look and touch, were obtained for granulometries bellow $500 \mu \mathrm{m}$. Higher granulometries resulted in part defects such as pinholes, heterogeneous surfaces, roughness and unwetted fibers, and therefore are not recommended. Wood content reduced the impact properties by $40 \%$ from $1316 \mathrm{~N}(10 \mathrm{wt} \%)$ to $789 \mathrm{~N}(30 \mathrm{wt} \%)$. This behavior is related to the poor sintering of materials revealed by a porous structure, lack of wettability and poor adhesion between PE/wood. The inability of WPC to sinter properly, causes the thickness of the part to increase. Among all, particles of 300-500 $\mu \mathrm{m}$ were those presenting better mechanical performance as good anchoring of irregular brick-shaped benefited those from a morphological point of view. The color of the parts was affected by the processing cycle applied. In conclusion, WPC are suitable materials for rotational molding applications and the production of sustainable products with differentiated wood aesthetics and color varying with the thermal processing cycle. The characteristics of the parts are affects by the granulometry and content of sawdust.

Author Contributions: C.I.M. was the scientific mentor of the work, conceiving and designing the experiments. S.R. and V.G. performed the experimental work and analyses of results. C.I.M. and V.G. analyzed the data and wrote the manuscript. All authors have read and agreed to the published version of the manuscript.

Funding: Project RoTMI-Rotomolding Technology and Materials Innovations (POCI-01-0247-FEDER33095), cofinanced by the European Regional Development Fund (FEDER) through the Operational Program for Competitiveness and Internationalization (POCI) under the "Portugal 2020" framework.

Institutional Review Board Statement: Not applicable.

Informed Consent Statement: Not applicable.

Data Availability Statement: Not applicable.

Acknowledgments: To the AF Fábrica de Madeiras, Lda (Portugal) for providing the sawdust material; to the financial support of the Project RoTMI-Rotomolding Technology and Materials Innovations (POCI-01-0247-FEDER-33095), cofinanced by the European Regional Development Fund (FEDER) through the Operational Program for Competitiveness and Internationalization (POCI) under the "Portugal 2020" framework; to the Portuguese Foundation for Science and Technology (FCT) through the National Funds References UIDB/05256/2020 and UIDP/05256/2020 provided to IPC.

Conflicts of Interest: The authors declare no conflict of interest.

\section{References}

1. Pereira, P.; Rosa, M.; Cioffi, M.; Benini, K.; Milanese, A.; Voorwald, H.; Mulinari, D. Vegetal fibers in polymeric composites: A review. Polímeros 2015, 25, 9-22. [CrossRef] 
2. Zhou, Y.; Stanchev, P.; Katsou, E.; Awad, S.; Fan, M. A circular economy use of recovered sludge cellulose in wood plastic composite production: Recycling and eco-efficiency assessment. Waste Manag. 2019, 99, 42-48. [CrossRef] [PubMed]

3. Sommerhuber, P.; Welling, J.; Krause, A. Substitution potentials of recycled HDPE and wood particles from post-consumer packaging waste in Wood-Plastic Composites. Waste Manag. 2015, 46, 76-85. [CrossRef]

4. McCormick, K.; Kautto, N. The Bioeconomy in Europe: An Overview. Sustainability 2013, 5, 2589-2608. [CrossRef]

5. Joustra, J.; Flipsen, B.; Balkenende, R. Circular design of composite products: A framework based on insights from literature and industry. Sustainability 2021, 13, 7223. [CrossRef]

6. Saheb, D.; Jog, J. Natural Fiber Polymer Composites: A Review. Adv. Polym. Technol. 1999, 18, 351-363. [CrossRef]

7. Venkatesh, G.; Deb, A.; Karmarkar, A.; Gurumoorthy, B. Eco-Friendly Wood Polymer Composites for Sustainable Design Applications. In CIRP Design 2012; Springer: Bangalore, India, 2012; pp. 399-408, ISBN 9781447145073.

8. Petchwattana, N.; Naknaen, P.; Narupai, B. A circular economy use of waste wood sawdust for wood plastic composite production: Effect of bio-plasticiser on the toughness. Int. J. Sustain. Eng. 2019, 13, 398-410. [CrossRef]

9. Robledo-Ortíz, J.; González-López, M.; Rodrigue, D.; Gutiérrez-Ruiz, J.; Prezas-Lara, F.; Pérez-Fonseca, A. Improving the Compatibility and Mechanical Properties of Natural Fibers/Green Polyethylene Biocomposites Produced by Rotational Molding. J. Polym. Environ. 2020, 28, 1040-1049. [CrossRef]

10. Pokhrel, G.; Gardner, D.J.; Han, Y. Properties of wood-plastic composites manufactured from two different wood feedstocks: Wood flour and wood pellets. Polymers 2021, 13, 2769. [CrossRef]

11. Gardner, D.J.; Han, Y.; Wang, L. Wood-Plastic composite technology. Curr. For. Rep. 2015, 1, 139-150. [CrossRef]

12. Ibrahim, M.; Badrishah, N.S.; Sa'ude, N.; Ibrahim, M.H.I. Sustainable natural bio composite for FDM feedstocks. Appl. Mech. Mater. 2014, 607, 65-69. [CrossRef]

13. Kohl, D.; Link, P.; Böhm, S. Wood as a Technical Material for Structural Vehicle Components. Procedia CIRP 2016, 40, 557-561. [CrossRef]

14. Thompson, D.W.; Hansen, E.N.; Knowles, C.; Muszynski, L. Opportunities for wood plastic composite products in the U.S. highway construction sector. BioResources 2010, 5, 1336-1352. [CrossRef]

15. Santoni, A.; Bonfiglio, P.; Fausti, P.; Marescotti, C.; Mazzanti, V.; Mollica, F.; Pompoli, F. Improving the sound absorption performance of sustainable thermal insulation materials: Natural hemp fibres. Appl. Acoust. 2019, 150, 279-289. [CrossRef]

16. Asyraf, M.R.M.; Ishak, M.R.; Sapuan, S.M.; Yidris, N. Influence of Additional Bracing Arms as Reinforcement Members in Wooden Timber Cross-Arms on Their Long-Term Creep Responses and Properties. Appl. Sci. 2021, 11, 2061. [CrossRef]

17. Rizki, M.; Tamai, Y.; Koda, K.; Kojima, Y.; Terazawa, M. Wood density variations of tropical wood species: Implications to the physical properties of sawdust as substrate for mushroom cultivation. Wood Res. 2010, 1, 34-39.

18. Hanana, F.; Rodrigue, D. Rotational molding of polymer composites reinforced with natural fibers. Plast. Eng. 2015, 71, 28-31. [CrossRef]

19. León, L.; Escocio, V.; Visconte, L.; Junior, J.; Pacheco, E. Rotomolding and polyethylene composites with rotomolded lignocellulosic materials: A review. J. Reinf. Plast. Compos. 2020, 39, 459-472. [CrossRef]

20. Affiliation of Rotational Moulding Organisations. ARMO Rotational Moulding Product Showcase. Available online: https: //issuu.com/rotoworld/docs/2017_armo_rotational_moulding_produ (accessed on 2 August 2021).

21. Crawford, R.; Kearns, M. Practical Guide to Rotational Moulding; iSmithers Rapra Publishing: Shrewsbury, UK, 2003 ; ISBN 1859573878.

22. Crawford, R.; Gibson, S. Rotational molding: Some Basics. Pop. Plast. Packag. 2012, 10, 26-28.

23. Crawford, R.; Throne, J. Processing. In Rotational Molding Technology; William Andrew Publishing: New York, NY, USA, 2002; pp. 201-306, ISBN 1884207855.

24. Nugent, P. Rotational Molding. In Applied Plastics Engineering Handbook: Processing, Materials, and Applications; Kutz, M., Ed.; Elsevier: Reading, PA, USA, 2017; ISBN 978-0-323-39040-8.

25. Fletes, R.; López, E.; Sánchez, F.; Mendizábal, E.; Núñez, R.; Rodrigue, D.; Gudiño, P. Morphological and mechanical properties of bilayers wood-plastic composites and foams obtained by rotational molding. Polymers 2020, 12, 503. [CrossRef]

26. Oliveira, M.; Cramez, M.; Crawford, R. Structure-property relationships in rotationally moulded polyethylene. J. Eng. Appl. Sci. 1996, 31, 2227-2240. [CrossRef]

27. Oliveira, M.J.; Cramez, M.C.; Oliveira, M.J.; Cramez, M.C. Rotational Molding of polyolefins: Processing, morphology and properties. J. Macromol. Sci. Part B 2001, 40, 457-471. [CrossRef]

28. Greco, A.; Ferrari, F.; Buccoliero, M.; Trono, G. Thermal and mechanical analysis of polyethylene homo-composites processed by rotational molding. Polymers 2019, 11, 528. [CrossRef]

29. Saka, S. Structure and Chemical Composition of Wood as a Natural Composite Material. In Recent Research on Wood and Wood-Based Materials; Elsevier: Amsterdam, The Netherlands, 1993; pp. 1-20. [CrossRef]

30. Rowell, R.; Pettersen, R.; Tshabalala, M. Cell Wall Chemistry. In Handbook of Wood Chemistry and Wood Composites, 2nd ed.; CRC Press: Boca Raton, FL, USA, 2012; pp. 33-72, ISBN 9781439853818.

31. Torres, F.; Aguirre, M. Rotational moulding and powder processing of natural fibre reinforced thermoplastics. Int. Polym. Process. 2003, 18, 204-210. [CrossRef]

32. Arribasplata-Seguin, A.; Quispe-Dominguez, R.; Tupia-Anticona, W.; Acosta-Sullcahuamán, J. Rotational molding parameters of wood-plastic composite materials made of recycled high density polyethylene and wood particles. Compos. Part B 2021, 217, 1-18. [CrossRef] 
33. Cisneros-López, E.; González-López, M.; Pérez-Fonseca, A.; González-Núñez, R.; Rodrigue, D.; Robledo-Ortíz, J. Effect of fiber content and surface treatment on the mechanical properties of natural fiber composites produced by rotomolding. Compos. Interfaces 2016, 24, 35-53. [CrossRef]

34. Oliveira, M.; Pickering, K.; Sunny, T.; Lin, R. Rotational Moulding of Polyethylene Reinforced with Alkali Treated Hemp Fibre. In Chemeca Conference; Institution of Chemical Engineers: Queenstown, New Zealand, 2018; pp. 1-9, ISBN 9781911446682.

35. Cisneros-Lopez, E.; Perez-Fonseca, A.; Fuentes-Talavera, F. Rotomolded Polyethylene-Agave Fiber Composites: Effect of Fiber Surface Treatment on the Mechanical Properties. Polym. Eng. Sci. 2016, 8, 856-865. [CrossRef]

36. Bledzki, A.; Reihmane, S.; Gassan, J. Thermoplastics reinforced with wood fillers: A literature review. Polym.-Plast. Technol. Eng. 1998, 37, 451-468. [CrossRef]

37. Hanana, F.; Rodrigue, D. Effect of particle size, fiber content, and surface treatment on the mechanical properties of maplereinforced LLDPE produced by rotational molding. Polym. Polym. Compos. 2020, 29, 343-353. [CrossRef]

38. Hanana, F.; Rodrigue, D. Rotational Molding of Self-Hybrid Composites Based on Linear Low-Density Polyethylene and Maple Fibers. Polym. Compos. 2017, 39, 4094-4103. [CrossRef]

39. Raymond, A.; Rodrigue, D. Foams and wood composite foams produced by rotomolding. Cell. Polym. 2013, 32, 199-212. [CrossRef]

40. Jayaraman, K.; Lin, R.; Bose, D.; Maarouf, M. Natural Fibre-Reinforced Thermoplastics Processed by Rotational Moulding. Adv. Mater. Res. 2007, 29-30, 307-310. [CrossRef]

41. Wang, B.; Panigrahi, S.; Tabil, L.; Crerar, W. Pre-treatment of flax fibers for use in rotationally molded biocomposites. J. Reinf. Plast. Compos. 2007, 26, 447-463. [CrossRef]

42. Ortega, Z.; Monzón, M.; Benítez, A.; Kearns, M.; McCourt, M.; Hornsby, P. Banana and abaca fiber-reinforced plastic composites obtained by rotational molding process. Mater. Manuf. Process. 2013, 28, 879-883. [CrossRef]

43. López-Banuelos, R.; Moscoso, F.; Ortega-Gudino, P. Rotational Molding of Polyethylene Composites Based on Agave Fibers. Polym. Eng. Sci. 2012, 46, 486-492. [CrossRef]

44. Hanana, F.; Chimeni, D.; Rodrigue, D. Morphology and mechanical properties of maple reinforced LLDPE produced by rotational moulding: Effect of fibre content and surface treatment. Polym. Polym. Compos. 2018, 26, 299-308. [CrossRef]

45. Martins, C.; Gil, V. Processing-Structure-Properties of Cork Polymer Composites. Front. Mater. 2020, 7, 1-12. [CrossRef]

46. Abhilash, S.; Singaravelu, D. Effect of Fiber Content on Mechanical and Morphological Properties of Bamboo Fiber-Reinforced Linear Low-Density Polyethylene Processed by Rotational Molding. Trans. Indian Inst. Met. 2020, 73, 1549-1554. [CrossRef]

47. Bekhta, P.; Niemz, P. Effect of high temperature on the change in color, dimensional stability and mechanical properties of spruce wood. Holzforschung 2003, 57, 539-546. [CrossRef]

48. Pontes, A.; Ferreira, E.; Mendes, J.; Fonseca, J.; Cramez, M.; Pouzada, A. O Molde; Revista da Cefanol: Marinha Grande, Portugal, 2014; pp. 23-29.

49. Guo, Q.; Chen, X.; Liu, H. Experimental research on shape and size distribution of biomass particle. Fuel 2012, 94, 551-555. [CrossRef]

50. Datasheet of ADVANCENE EM-3405-UVH Medium Density Polyethylene (MDPE). Available online: https://www.ulprospector. com/plastics/en/datasheet/381003/advancene-em-3405-uvh (accessed on 4 April 2021).

51. González-Díaz, E.; Alonso-López, J. Characterization by thermogravimetric analysis of the wood used in Canary architectural heritage. J. Cult. Herit. 2017, 23, 111-118. [CrossRef]

52. Poletto, M.; Zattera, A.; Forte, M.; Santana, R. Thermal decomposition of wood: Influence of wood components and cellulose crystallite size. Bioresour. Technol. 2012, 109, 148-153. [CrossRef]

53. Sebio-Puñal, T.; Naya, S.; López-Beceiro, J.; Tarrío-Saavedra, J.; Artiaga, R. Thermogravimetric analysis of wood, holocellulose, and lignin from five wood species. J. Therm. Anal. Calorim. 2012, 109, 1163-1167. [CrossRef]

54. Wei, L.; McDonald, A.; Freitag, C.; Morrell, J. Effects of wood fiber esterification on properties, weatherability and biodurability of wood plastic composites. Polym. Degrad. Stab. 2013, 98, 1348-1361. [CrossRef]

55. Gebke, S.; Thümmler, K.; Sonnier, R.; Tech, S.; Wagenführ, A.; Fischer, S. Flame retardancy of wood fiber materials using phosphorus-modified wheat starch. Molecules 2020, 25, 335. [CrossRef]

56. Kučerová, V.; Lagaňa, R.; Výbohová, E.; Hýrošová, T. The Effect of Chemical Changes during Heat Treatment on the Color and Mechanical Properties of Fir Wood. BioResources 2016, 11, 9079-9094. [CrossRef]

57. Akkuş, M.; Budakçı, M. Determination of color-changing effects of bleaching chemicals on some heat-treated woods. J. Wood Sci. 2020, 66, 1-14. [CrossRef]

58. Torres, F.G.; Carrillo, M.; Cubillas, M.L. Melt densification of polymeric powder beds filled with natural fibres. Polym. Polym. Compos. 2006, 14, 691-699. [CrossRef]

59. Ward-Perron, N.; Rodrigue, D. Analysis of wood particle drying for rotomolding application. In Proceedings of the 70th Annual Technical Conference of the Society of Plastics Engineers 2012, ANTEC 2012, Orlando, FL, USA, 2-4 April 2012; Volume 3, pp. 2259-2262.

60. Dikobe, D.; Luyt, A. Effect of Filler Content and Size on the Properties of Ethylene Vinyl Acetate Copolymer-Wood Fiber Composites. J. Appl. Polym. Sci. 2007, 103, 3645-3654. [CrossRef]

61. Marcovich, N.; Villar, M. Thermal and mechanical characterization of linear low-density polyethylene/wood flour composites. J. Appl. Polym. Sci. 2003, 90, 2775-2784. [CrossRef] 